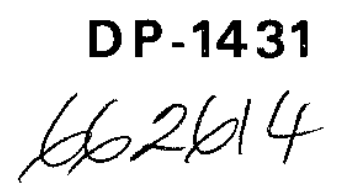

TIS FILE

RECORD COPY

\title{
ANALYSIS OF TRANSIENTS IN THE SRP TEST PILE
}

J. P. CHURCH

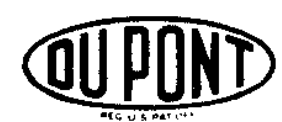

SAVANNAH RIVER LABORATORY AIKEN, SOUTH CAROLINA 29801 


\title{
NOTICE
}

This report was prepared as an account of work sponsored by the United States Government. Neither the United States nor the United States Energy Research and Development Administration, nor any of their contractors, subcontractors, or their employees, makes any warranty, express or implied, or assumes any legal liability or responsibility for the accuracy, completeness or usefulness of any information, apparatus, product or process disclosed, or represents that its use would not infringe privately owned rights.

\author{
Printed in the United States of America \\ Available from \\ National Technical Information Service \\ U.S. Department of Commerce \\ 5285 Port Roval Road \\ Springfield, Virginia 22161 \\ Price: Printed Copy $\$ 4.00$ : Microfiche $\$ 2.25$
}


Distribution Category: UC- 80

\section{ANALYSIS OF TRANSIENTS IN THE SRP TEST PILE}

by

J. P. Church

Approved by

P. L. Roggenkamp, Research Manager

Reactor Physics Division

Publication Date: November 1976

E. I. DU PONT DE NEMOURS AND COMPANY SAVANNAH RIVER LABORATORY

AIKEN, SOUTH CAROLINA 29801

PREPARED FOR THE U. S. ENEAGY RESEARCH AND DEVELOPMENT ADMINISTRATION UNDER CONTRACT AT(OT-2)-1 


\section{ABSTRACT}

Analysis of the hypothetical upper limit accident in the Savannah River Test Pile showed that the offsite thyroid dose from fission product release would be $<2.2 \times 10^{-3}$ of the 10 -CFR100 guideline dose for $95 \%$ of measured meteorological conditions. Offsite whole body dose would be negligible. The Test Pile was modified to limit the length of test piece that can be charged to the pile. These modifications reduce the potential offsite dose to $<2.2 \times 10^{-5}$ of the regulatory guidelines.

The Test Pile is a large, graphite-moderated, nuclear reactor for testing the reactivity worth of reactor components. Assessment of Test Pile safety included calculations of transients initiated by a variety of reactivity additions that were either terminated or not terminated by safety systems. Reactivity addition mechanisms considered were abnormally driving control rods out of the pile and charging abnormal test pieces into the pile. The transients were evaluated in the adiabatic approximation in which three-dimensional calculations of static flux shapes and reactivity were superimposed on point reactor kinetics calculations. Negative reactivity feedback effects appropriate for the pile and the temperature dependence of material properties, such as specific heat and thermal conductivity, were included.

The results show that, for the worst initiators, safety systems can prevent the temperature rise from exceeding $1^{\circ} \mathrm{C}$ anywhere in the Test Pile. If the safety systems do not function, the pile temperatures will increase until the transient is ended by the inherent negative reactivity effects, including the melting of some fuel. 


\section{CONTENTS}

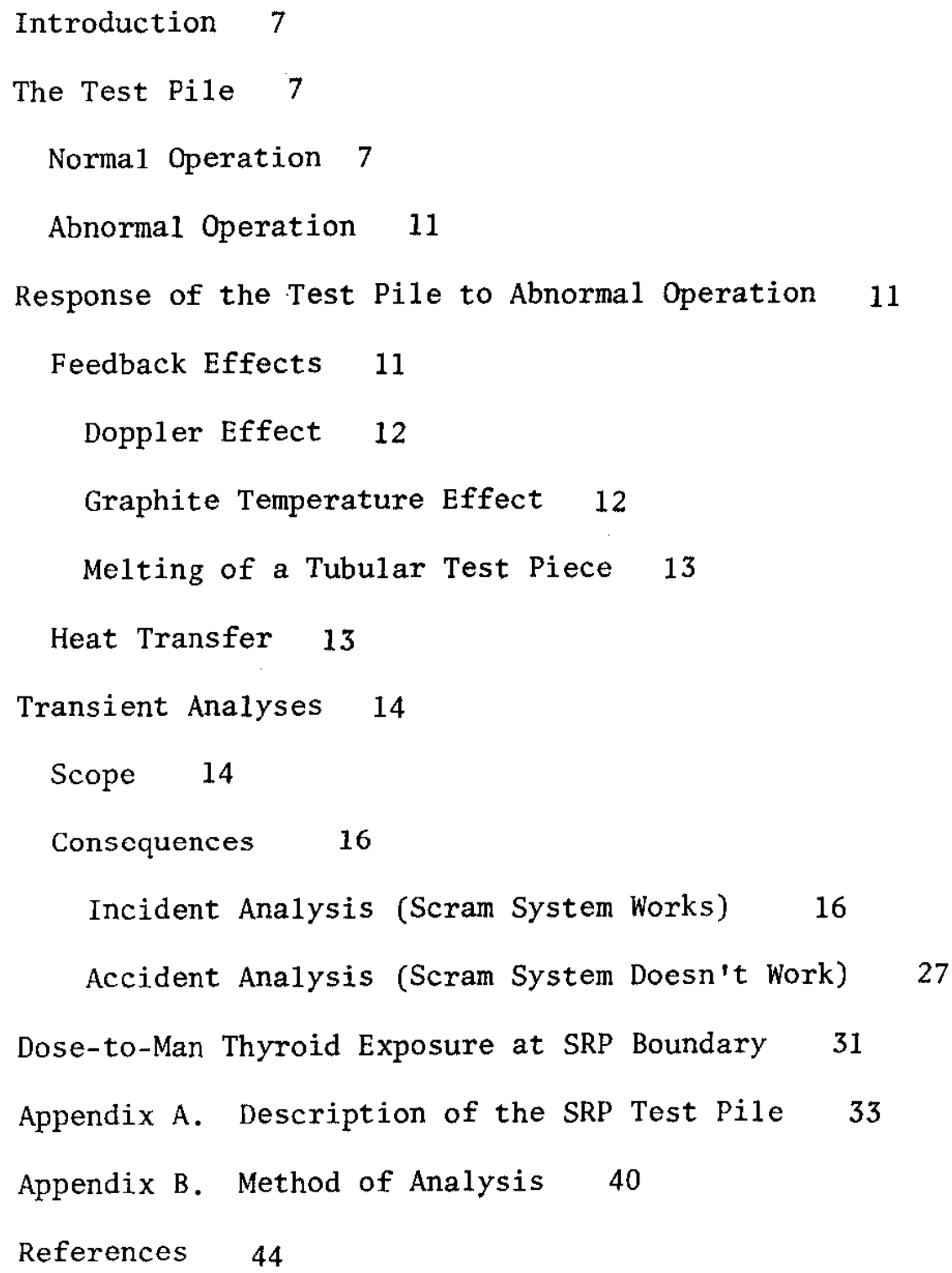




\section{LIST OF FIGURES}

1 North Face of Test Pile 8

2 Arrangement of Graphite Packing for Core of Test Pile 9

3 Test Pile Cross Section 10

$4 \quad$ Safety Rod Reactivity Transient 17

5 Coarse Rod Driveout Incident for Different Initial Power Levels 18

6 Coarse Rod Driveout Incident with Different Scram Setpoints 19

7 Shim Rod Driveout Incident with Different Scram Setpoints 20

$8 \quad$ Reactivity Transients for Unauthorized Test Pieces

9 Reactivity Addition to Test Pile as Limited by Scram System Setpoints (12.5 ft U-A1 rod charged at $45 \mathrm{ft} / \mathrm{min}) \quad 23$

10 Reactivity Addition to Test Pile as Limited by Scram System Setpoints $(12.5 \mathrm{ft}$ U-A1 rod charged at $60 \mathrm{ft} / \mathrm{min}) \quad 23$

11 Reactivity Addition to Test Pile as Limited by Scram System Setpoints (12.5 ft U-A1 rod charged at $90 \mathrm{ft} / \mathrm{min}) \quad 24$

12 Power and Temperature Transients for U-AI Test Piece Incident 24

13 Reactivity Addition to Test Pile as Limited by Scram System Setpoints (2.1-ft U-Al rod charged at $45 \mathrm{ft} / \mathrm{min}$ ) 25

14 Reactivity Addition to Test Pile as Limited by Scram System Setpoints (2.1-ft U-A1 rod charged at $60 \mathrm{ft} / \mathrm{min}$ ) 25

15 Reactivity Addition to Test Pile as Limited by Scram System Setpoints (2.1-ft U-Al rod charged at $90 \mathrm{ft} / \mathrm{min}) \quad 26$ 
16 Reactor Transients for Control Rod Driveout Accidents $\quad 28$

17 Temperature Transients for Insertion of Unauthorized Uranium Metal Assemb1y 29

18 Total Number of Fissions in Molten Metal when Unauthorized U-Al Assemblies are Charged at $90 \mathrm{ft} / \mathrm{min}$ to Test Pile 30

A-1 Location of Test Pile on the Savannah River Plant 33

A-2 Scram Circuit Response and Safety Rod Insertion Times $\quad 39$

B-1 Transient Analysis Model for Core of Test Pile 40

B-2 Face Map of Test Pile Showing Relative Values for Peak Axial Power Production 43

\section{LIST OF TABLES}

1 Reactivity Worth of Test Pieces When Displacing

a Depleted Target Standard 21

2 Reactivity Worth of U-A1 2.1-ft Test Piece when Displacing a Depleted Target Standard 26

3 Exposure at Plant Boundary Due to Fission Product Release from Molten Metal 32

A-1 Test Pile Control Rod and Safety Rod Systems 36

A-2 Safety System Response Times for the SRP Test Pile 38 
ANALYSIS OF TRANSIENTS IN THE SRP TEST PILE

\section{INTRODUCTION}

The Test Pile is a large critical nuclear reactor at the Savannah River Plant (SRP). The pile is designed to measure the reactivity of samples of uranium metal fuel and target assemblies, sample bottles of $\mathrm{D}_{2} \mathrm{O}, \mathrm{GdO}_{2}-\mathrm{D}_{2} \mathrm{O}$, borated $\mathrm{H}_{2} \mathrm{O}$, borated steel shot, and a variety of other materials and reactor components.

As part of a periodic reassessment of the safety of the pile, the transient response of the pile to various abnormal conditions was studied. Several hypothetical causes of abnormal operation for two broad classes of accidents were analyzed with (1) the automatic shutdown (scram) systems fully operational, and (2) inoperative scram systems. If the scram systems do not work, other inherent shutdown mechanisms can add negative reactivity to the pile and end the transient. These mechanisms were included in the analysis.

A hypothetical upper limit accident was postulated. The results of this accident were then analyzed to determine exposure to offsite personnel under $95 \%$ of the measured meteorological conditions.

\section{THE TEST PILE}

The Test Pile is described in detail in Appendix A. The brief description given below will give only an overview of the features pertinent to the transient analysis.

The Test Pile shown in Figures 1,2 , and 3 is a large critical nuclear reactor that is moderated with graphite and fueled with natural uranium slugs. The fuel slugs lie in horizontal channels in the graphite. A helium atmosphere fills the gap between the fuel and graphite. A test hole, which is open to the atmosphere, extends horizontally through the pile. Test pieces are inserted into the test hole on a motor-driven graphite stringer.

\section{Normal Operation}

Three absorbing rods (fine, shim, and coarse) control the pile during operation. These control rods automatically drive horizontally into the pile's west face under scram conditions. The test piece enters the north face. 


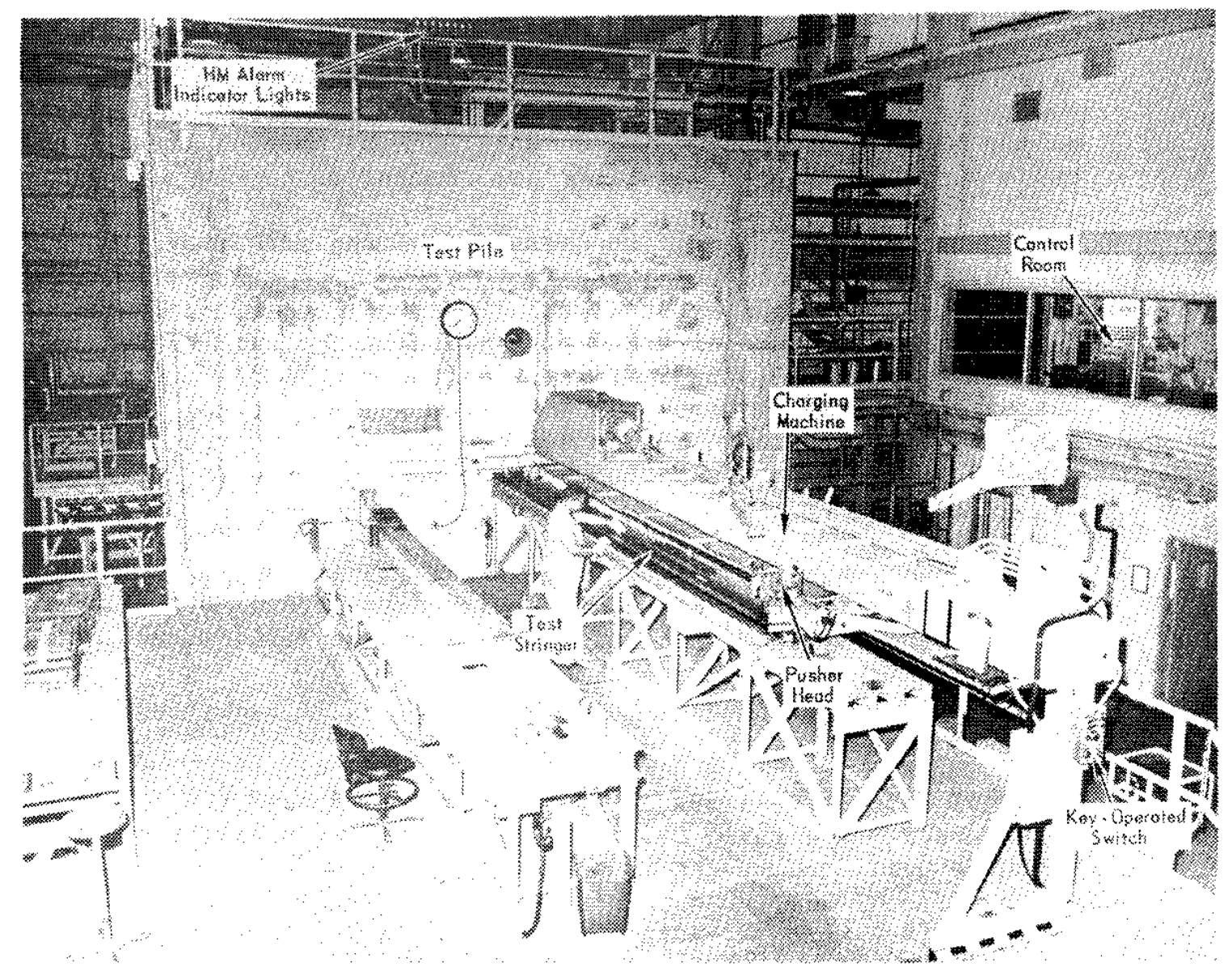

FGuRE \& North face of Test pile 


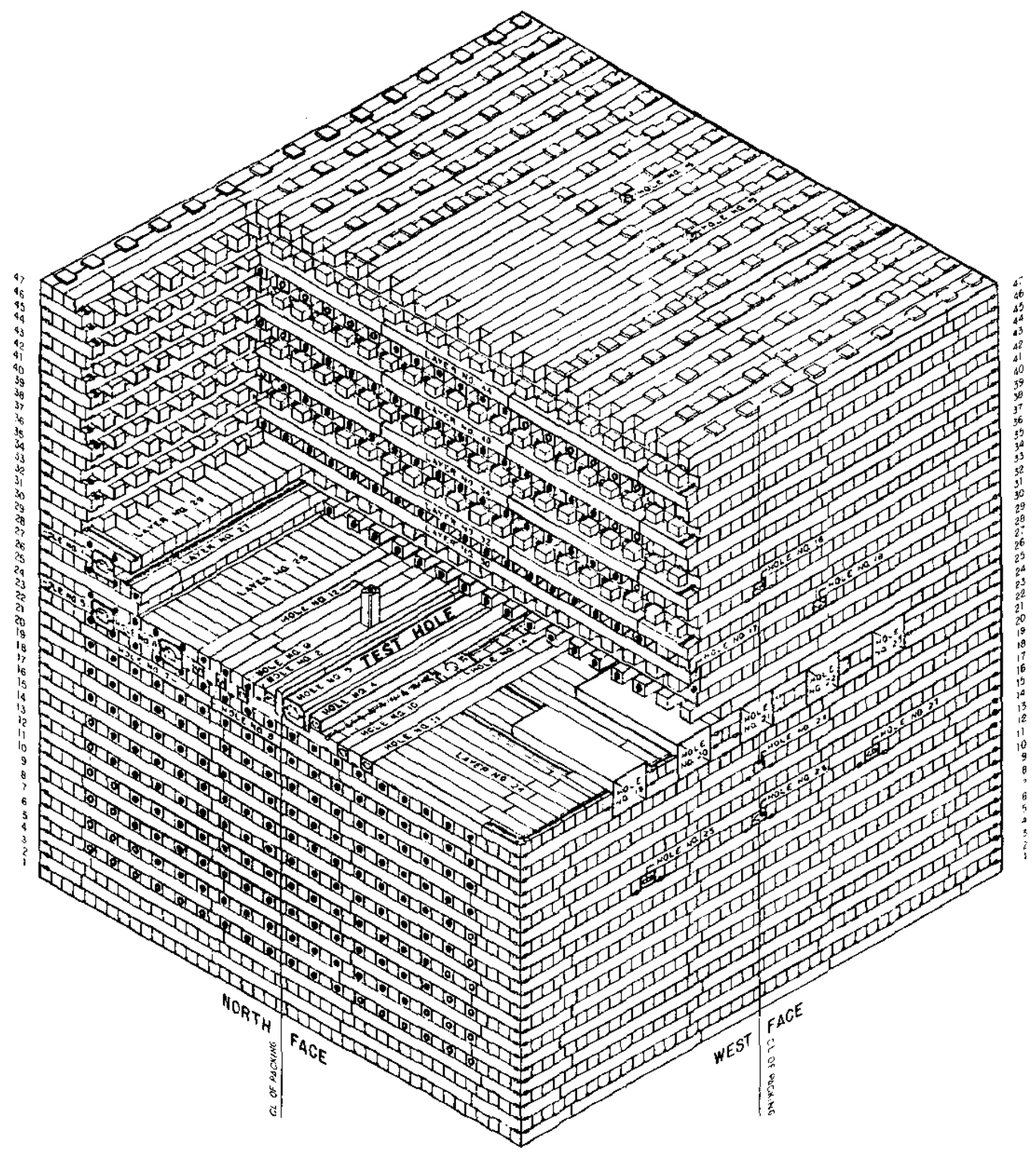

FIGURE 2. Arrangement of Graphite Packing for Core of Test Pile 


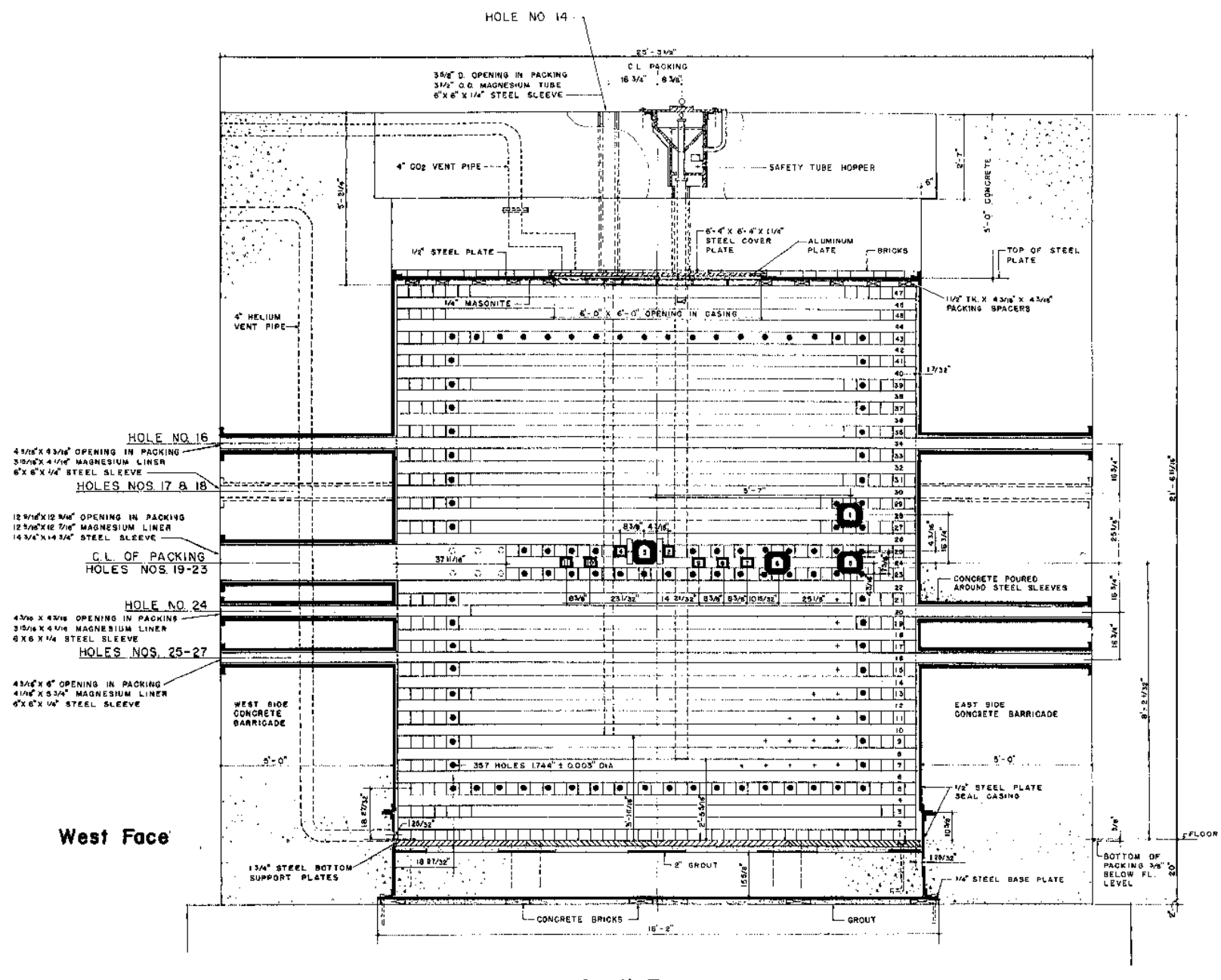

South Face

FIGURE 3. Test Pile Cross Section 
Three safety rods provide additional shutdown capability in the event of an automatic scram. One of these safety rods is pulled horizontally into the pile from the west face by a counterweight. The other two are vertical safety rods that fall freely into the pile from the top of the pile.

Instrumentation initiates an automatic shutdown (scram) of the Test Pile if the flux level is too high or the period is too short. When a scram occurs, the horizontal and vertical safety rods enter the pile, the fine and coarse rods are driven into the pile, and the graphite stringer stops moving.

\section{Abnormal Operation}

Effective controls and written procedures, together with numerous safety features, provide for safe operation of the Test Pile. Nevertheless, abnormal operation is possible.

Possible causes of abnormal operation and their consequences were investigated. The results presented later in this report show that charging a too-reactive test piece has worse consequences than any other identified or postulated problem.

The error that would cause the greatest increase in the reactivity of the Test Pile is charging an assembly, or portion of an assembly, having a high ${ }^{235} \mathrm{U}$ content. Procedures prohibit short pieces of such assemblies from being in the same building with the Test Pile. But full-1ength U-Al assemblies with high ${ }^{2}{ }^{5} U$ content are tested in a subcritical reactor near the Test Pile, and it is credible that these assemblies may be charged by mistake to the Test Pile.

\section{RESPONSE OF THE TEST PILE TO ABNORMAL OPERATION}

\section{Feedback Effects}

Abnormal operation of the Test Pile will automatically initiate a scram. The operator may also shut down the pile manually.

If the pile is not shut down by these methods, the reactor power would increase and cause the fuel and graphite temperatures to increase. Three feedback effects then provide negative reactivity to the pile: These effects are (1) the prompt decrease in reactivity due to Doppler broadening of the ${ }^{238} \mathrm{U}$ resonances when the fuel temperature rises, (2) the delayed decrease in reactivity due to heating the graphite moderator, and (3) the decrease in reactivity caused by the increased self-shielding that occurs, if a tubular test piece (with positive reactivity worth) melts. 


\section{Doppler Effect}

The increase in fuel temperature would produce an immediate Doppler broadening of the ${ }^{2{ }^{3}} \mathrm{U}$ resonances and decrease the reactivity of the pile. This reactivity change was calculated with the GLASS transport theory code, ${ }^{1}$ which computes few-group cell parameters, and the GRIM few-group diffusion theory code, ${ }^{2}$ which computes flux shapes and reactivity for the reactor condition. GLASS calculates group diffusion parameters for input to GRIM, and GRIM calculates the reactivity of the pile. This reactivity change was calculated for the temperature range of $20^{\circ} \mathrm{C}$ to $1100^{\circ} \mathrm{C}$. A least squares polynomial was computed for these data to be

$$
\mathrm{k}_{\mathrm{F}}(\mathrm{T})=1.0116+\mathrm{T}\left[0.2168 \times 10^{-4}+\mathrm{T}\left(6.2536 \times 10^{-9}-0.9958 \times 10^{-12} \mathrm{~T}\right)\right]
$$

where $\mathrm{T}$ is the metal temperature in ${ }^{\circ} \mathrm{C}$. At $100^{\circ} \mathrm{C}$, this expression gives a temperature coefficient of $-2.05 \times 10^{-5} \mathrm{k} /{ }^{\circ} \mathrm{C}$, in agreement with values measured in the similar Hanford Test Reactor. ${ }^{3}$ At $1100^{\circ} \mathrm{C}$, near the melting point of the uranium fuel, this expression gives a coefficient of $-1.22 \times 10^{-5} \mathrm{k} /{ }^{\circ} \mathrm{C}$. Thus, as the fuel temperature increases, the Doppler effect becomes smaller.

\section{Graphite Temperature Effect}

As the power transient continues, heat is radiated and conducted from the fuel to the surrounding graphite. This transfer of heat is a slow process for two reasons. First, radiation does not transfer significant heat until fuel temperatures of $300^{\circ} \mathrm{C}$ to $400^{\circ} \mathrm{C}$ are reached. Second, the fuel slug has only line contact with the graphite. Heat conduction across the helium gap between fuel and graphite, or across the air gap in the test hole, is slow because helium and air have poor thermal conductivity relative to liquid coolants or metal contacts.

When the graphite temperature finally increases, both the resulting reduced density of the graphite and increased thermal motion of the graphite nuclei reduces its effectiveness as a moderator, and the reactivity decreases. The slow rate of heat transfer thus results in a delayed negative reactivity feedback.

The reactivity effect of heating the graphite was calculated with the GLASS ${ }^{2}$ and GRIM $^{2}$ codes for the temperature range of $20^{\circ} \mathrm{C}$ to $727^{\circ} \mathrm{C}$. The domain of interest extends to $800^{\circ} \mathrm{C}$; therefore, the computed data were extrapolated graphically beyond $727^{\circ} \mathrm{C}$ to provide a basis for a polynomial fit over an extended range. A leastsquares polynomial was computed for these data to be

$$
\begin{aligned}
\mathrm{k}_{\mathrm{G}}(\mathrm{T})= & 1.0108+\mathrm{T}\left\{-0.4580 \times 10^{-4}+\mathrm{T}\left[2.168 \times 10^{-8}+\right.\right. \\
& \left.\left.\mathrm{T}\left(-0.4870 \times 10^{-11}+3.949 \times 10^{-16} \mathrm{~T}\right)\right]\right\}
\end{aligned}
$$


At $100^{\circ} \mathrm{C}$, this expression gives a temperature coefficient of $-4.16 \times 10^{-5} \mathrm{k} /{ }^{\circ} \mathrm{C}$; at $800^{\circ} \mathrm{C}$, the coefficient is $-1.96 \times 10^{-5} \mathrm{k} /{ }^{\circ} \mathrm{C}$. Like the Doppler coefficient, the graphite temperature coefficient becomes numerically smaller as the temperature increases.

\section{Melting of a Tubular Test Piece}

The test piece will melt if the temperature coefficients do not reduce the power quickly enough. The graphite stringer which holds the test piece has a trough along its length that will contain the molten metal. Thus, melting of the test piece does not remove the reactive material from the core, but would cause a tubular test piece to form a more rod-like shape with a smaller surface area. The self-shielding of the test piece would increase. If the test piece has positive reactivity, then the total reactor reactivity would decrease. The reactivity decrease was calculated with the GLASS ${ }^{1}$ and GRIM $^{2}$ codes for each test piece considered.

\section{Heat Transfer}

In the Test Pile, fuel radiates and conducts heat to graphite. However, conduction is the only significant means of axial heat transfer along a fuel assembly or graphite fuel channe1, and is the only means of heat transfer between adjacent graphite blocks. Conduction transfers heat rather slowly between graphite and the fuel slugs (or test piece) because of the low thermal conductivity of the helium and air in the gaps between the metal and graphite. However, if the metal melts in either a fuel channel or the test hole, heat transfer rates increase because of the improved contact between the metal and graphite.

An oxide film exists on the Test Pile fuel. When the fuel melts and contacts the graphite, this film reduces the conduction of heat from fuel to graphite. The true thickness and the thermal conductivity of such a film are unknown. A film thickness (h) of $0.005 \mathrm{in}$. and a thermal conductivity (C) of $0.1 \mathrm{pcu} /\left(\mathrm{hr}-\mathrm{ft}-{ }^{\circ} \mathrm{C}\right)$ are assumed. A pcu is the quantity of heat required to increase the temperature of one pound of water $1{ }^{\circ} \mathrm{C}$. The thermal conductivity of $\mathrm{UO}_{2}$ is about $2.0 \mathrm{pcu} /\left(\mathrm{hr}-\mathrm{ft}-{ }^{\circ} \mathrm{C}\right)$, whereas the assumed value of 0.1 is about that of dry sand. Thermal conduction depends on the ratio $C / h$. Because $h$ is unknown, $C$ is specified as 0.1 .

This conservative choice for $\mathrm{C}$ will compensate for uncertainties in $h$ and indicates less heat is transferred from fuel to graphite than would normally be expected. This reduction in heat flow has two effects. First, after melting begins, the heat retained in the metal will be greater; therefore, more metal will be computed 
to me1t, which would release more fission products, than if a larger $C_{f i l m}$ value were used. Second, the graphite temperature is lower and provides less reactivity feedback; therefore, the nuclear excursion is not ended as quickly as if a larger $C_{\text {film }}$ value were used. Again, a larger potential for release of fission products will be computed.

\section{TRANSIENT ANALYSES}

Scope

The transient response of the Test Pile was analyzed for two classes of hypothetical conditions: (1) incidents in which the automatic scram systems work, and (2) accidents in which the scram systems do not work. Parameters varied for these conditions were the reactivity initiators, the initial power levels, and the scram system setpoints (for incidents only).

For each class of transients, three initiators were postu1ates. These are:

(1) Coarse rod driveout while at very zow power - The stringer is assumed to be loaded with three slugs of the maximum authorized test piece $\left[0.95 \%{ }^{235} \mathrm{U}\right.$ uranium metal annular slug, about $8.4 \mathrm{in} .(21.3 \mathrm{~cm})$ long] and to be centered in the pile. The safety rods and the fine and shim rods are assumed to be out of the pile. The coarse rod then drives out at maximum speed $(8.5 \mathrm{~cm} / \mathrm{sec})$ beginning when the pile is at very low (mW) power. If the scram systems do not work, the final state of the pile is to have all control and safety rods out of the pile. The excess reactivity for this case is .0030 .

This condition of the Test Pile before the coarse rod drives out occurs only during the weekly test of the period and fluxlevel scram systems prior to startup of the pile. However, lessreactive, natural uranium slugs are normally in place, and the scram systems are set to trip at longer periods or lower flux levels than the normal scram setpoints.

(2) Shim rod driveout while at normal operation power The same test piece and the same excess reactivity are assumed as in (1). The safety rods and the fine and coarse rods were assumed to be out of the pile. The shim rod then drives out at maximum speed $(8.5 \mathrm{~cm} / \mathrm{sec})$ from its normal position (pile just critical, $\left.k_{\text {eff }}=1.0\right)$ while the pile is at operating power $(<50 \mathrm{~W})$.

This description prior to the shim rod driveout approximates a control rod driveout during normal operation of the pile with two exceptions. First, as in (1), the stringer normally contains 
less-reactive natural uranium slugs. Second, the fine rod is usually inserted part of the way into the pile. Thus, the reactivity available to the shim rod and the resulting power transient would be less than actually calculated for this analysis.

The pile state is about the same for this initiator as for (1) above. All rods are out of the pile at the end of the initiator transient, and the same test pieces are on the graphite stringer. Only the shape of the reactivity transient and the initial power are different than in (1).

(3) Uncuthorized test piece is inserted in the pile - Both uranium metal and uranium-aluminum (U-Al) assemblies are considered because the two types of assemblies have very different melting points and heat capacities. Typically, U-Al assemblies have a lower heat capacity, a lower melting point, and higher reactivity than uranium metal assemblies.

The uranium metal assembly is assumed to be enriched to $1.5 \%$ ${ }^{2}{ }^{5} \mathrm{U}$, and to be made of nested (inner + outer) pairs of annular slugs. This assumed assembly is more reactive than any assembly designed to date. The U-Al assembly is assumed to be a thin tube of about $2.4 \mathrm{in}$. $(6.0 \mathrm{~cm}) \mathrm{OD}$, and the ${ }^{235} \mathrm{U}$ content is varied up to $200 \mathrm{~g}^{235} \mathrm{U} / \mathrm{ft}$.

A $15.4 \mathrm{ft}(468 \mathrm{~cm})$ uranium metal, a $12.5 \mathrm{ft}(381 \mathrm{~cm})$ U-Al assembly, and shorter, $2.1 \mathrm{ft}(64 \mathrm{~cm})$, segments of such assemblies are considered.

For this initiator, the fine and shim rods are assumed to be positioned so the pile is critical $\left(\mathrm{k}_{\text {eff }}=1.0\right)$ with a depleted target standard (negative reactivity worth) before the test piece is charged. The coarse rod is completely out of the pile. The test piece is then assumed to be charged to the pile at the normal speed of $45 \mathrm{ft} / \mathrm{min}(22.9 \mathrm{~cm} / \mathrm{sec})$ and at faster speeds of $60 \mathrm{ft} / \mathrm{min}$ $(30.5 \mathrm{~cm} / \mathrm{sec})$ and $90 \mathrm{ft} / \mathrm{min}(45.7 \mathrm{~cm} / \mathrm{sec})$.

When the analysis was begun, the insertion of a $12.5 \mathrm{ft}$ $(381 \mathrm{~cm})$ U-Al assemb1y was considered a Hypothetical Upper Limit Accident. This accident was expected to occur with extremely low frequency. This accident was later considered to be a Design Basis Accident, and the test piece stringer was modified to prevent such an assembly from ever being charged to the Test Pile. This modification was made even though the analysis discussed later shows that the resulting offsite exposure from the upper limit accident would be less than 0.0022 of the 10-CFR-100 guidelines $^{4}$ for $95 \%$ of measured meteorological conditions. 


\section{Consequences}

Incident Analysis (Scram System Works)

\section{Scram System Reactivity Transient}

For the incident analysis, the automatic scram system is assumed to stop the withdrawal of control rods or the charging of a test piece, and to release the safety rods. However, only two of the three safety rods are assumed to enter the pile. This conservatism allows for single failures by the safety rod system. The reactivity worth and entry times of the three safety rods are different for each rod. To be conservative, the reactivity transient that simulates the safety rod insertion has, at any time, the minimum worth of any possible combination of two of the three rods.

The safety rod transient (Figure 4) has the time behavior of the horizontal and north vertical safety rod combination. The reactivity worth of these two safety rods was calculated assuming the shim rod is withdrawn 250 inches from the pile, and the fine and coarse rods are withdrawn completely from the pile.

Because the fine rod is normally partly in the pile, the worth of the two safety rods at any time would normally be greater than that shown in Figure 4. The combined reactivity worth of the two vertical rods when fully inserted is less than the combined worth of the horizontal and north vertical rods. So, to be conservative, the simulated safety rod transient ends when its maximum worth is equal to the worth of the two vertical rods. The total worth computed for the above configuration is $0.73 \% \mathrm{k}$.

The response times of the safety system are discussed in Appendix A.

No credit is taken for the emergency shot system in any of the analyses, nor for the drive-in of the fine and coarse rods by the automatic scram system.

\section{Incident Protection}

Incident analysis attempts to define the conditions for which the scram system will prevent a significant power rise that might disrupt the normal state of the reactor or cause undue risk to onsite personnel.

The criteria for safe operation of the Test Pile include the requirement that the dose to onsite personnel during normal operation must not exceed the radiation protection guidelines established in ERDA Manual, Chapter 0524.5 This criterion limits the permissible continuous operating power of the Test 


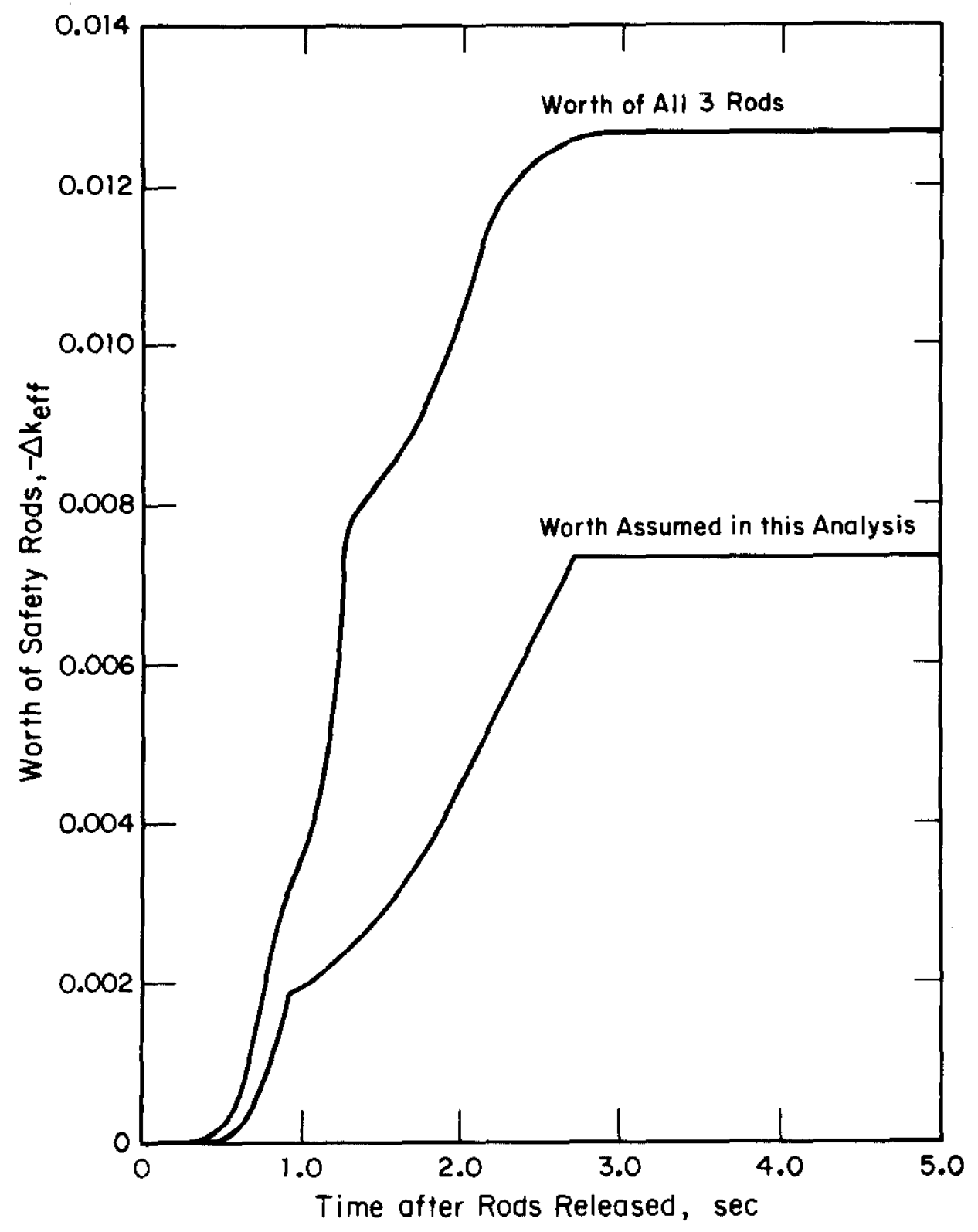

FIGURE 4. Safety Rod Reactivity Transient 
Pile. This power limit is defined as the Technical Limit. The Technical Limit for the Test Pile is 90 watts. The normal operating power is $230 \mathrm{~W}$. For most of this study, an initial operating power of $50 \mathrm{~W}$ is assumed. The power transients computed for this report are expressed in units of 90 watts.

The second criteria for safe operation is that the scram circuits must prevent a power rise that could disrupt the normal state of the reactor. In this study, scram setpoints are determined such that the temperature rise anywhere in the pilc would be less than $1^{\circ} \mathrm{C}$ in the worst case. Such a temperature rise would be too low to cause the helium gas pressure to exceed its pressure limit of 4 inches $(10 \mathrm{~cm})$ of water or to otherwise disrupt the normal state of the Test Pile.

\section{Coarse Rod Driveout While at Very Low Power}

Both the initial power level and the high-level flux monitor (HLFM) scram setpoint are varied for this initiator. For this incident, the pile response is about the same for two very different initial powers (Figure 5). With an HLFM set to signal a scram at $200 \mathrm{~W}$, no temperature rise is calculated for either the test piece or fue1 slugs.

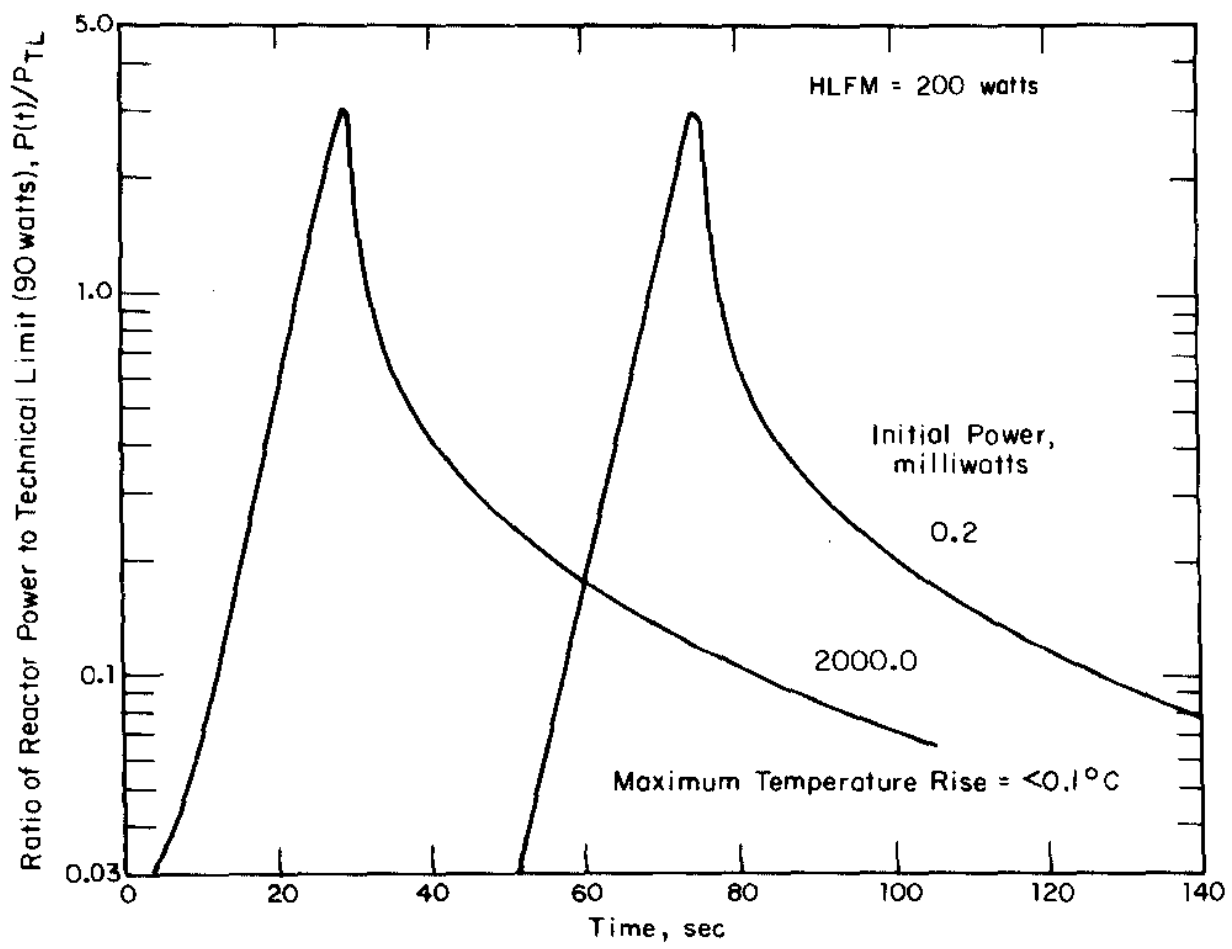

FIGURE 5. Coarse Rod Driveout Incident for Different Initial Power Levels 
The calculated power transient with different HLFM setpoints is shown in Figure 6 for an initial power of $2 \mathrm{~W}$ (the higher of the two powers in Figure 5). A setpoint that signals a scram at $55 \mathrm{~W}$ would prevent the power from exceeding the $90 \mathrm{~W}$ Technical Limit (although this latter limit applies only to continuous operation). If the flux monitors were set to scram at $200 \mathrm{~W}$ instead of the normal $55 \mathrm{~W}$, the Technical Limit would be exceeded, but there would be no detectable temperature rise in either the test piece or fue1 slugs.

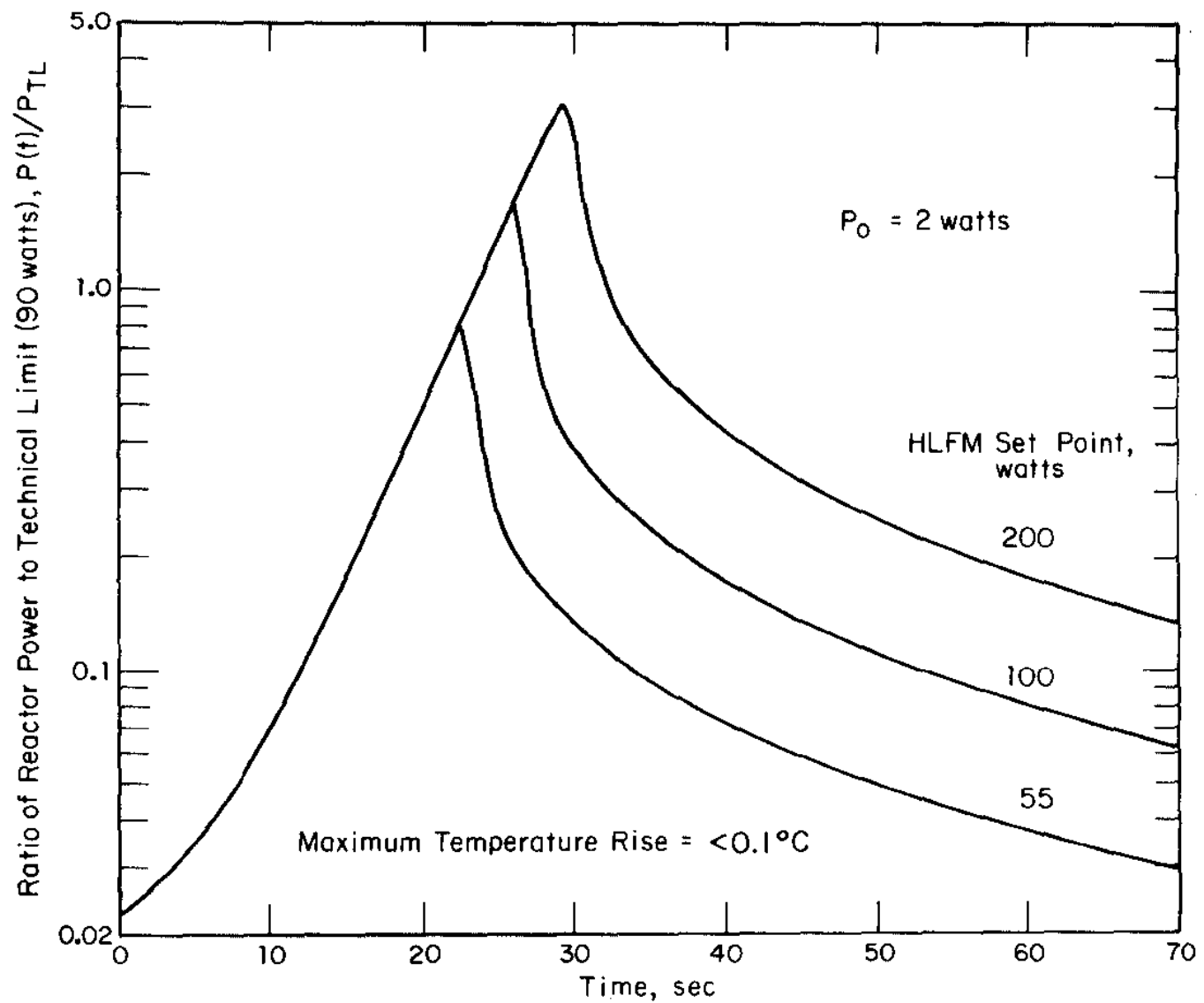

FIGURE 6. Coarse Rod Driveout Incident with Different Scram Setpoints 
Shim Rod Driveout While at Normal operating Power

The calculated power transient during a shim rod driveout with different HLFM setpoints is shown in Figure 7 for an initial operating power of $50 \mathrm{~W}$. The flux monitor scram setpoints are listed relative to the initial power. Thus, an HLFM setpoint of 2.0 corresponds to a scram signal occurring when the initial power doubles. Even if the flux monitors were set to trip at a factor of 10.0 increase in flux, there still would be no detectable temperature increase in either test piece or fuel.

\section{Unauthorized Test Piece Inserted in the Pile}

An unauthorized test piece can, if fully inserted, have a reactivity worth that exceeds the worth of the safety rods. Therefore, one of the most important functions of the scram system is to stop the motion of the test piece stringer. This action limits the reactivity that can be added to the pile so the pile is subcritical ( $\mathrm{k}_{\text {eff }}<1.0$ ) after the scram. Extensive transient calculations showed that the temperature rise would not exceed $1^{\circ} \mathrm{C}$ anywhere in the pile if 1 ) the pile were subcritical with the safety

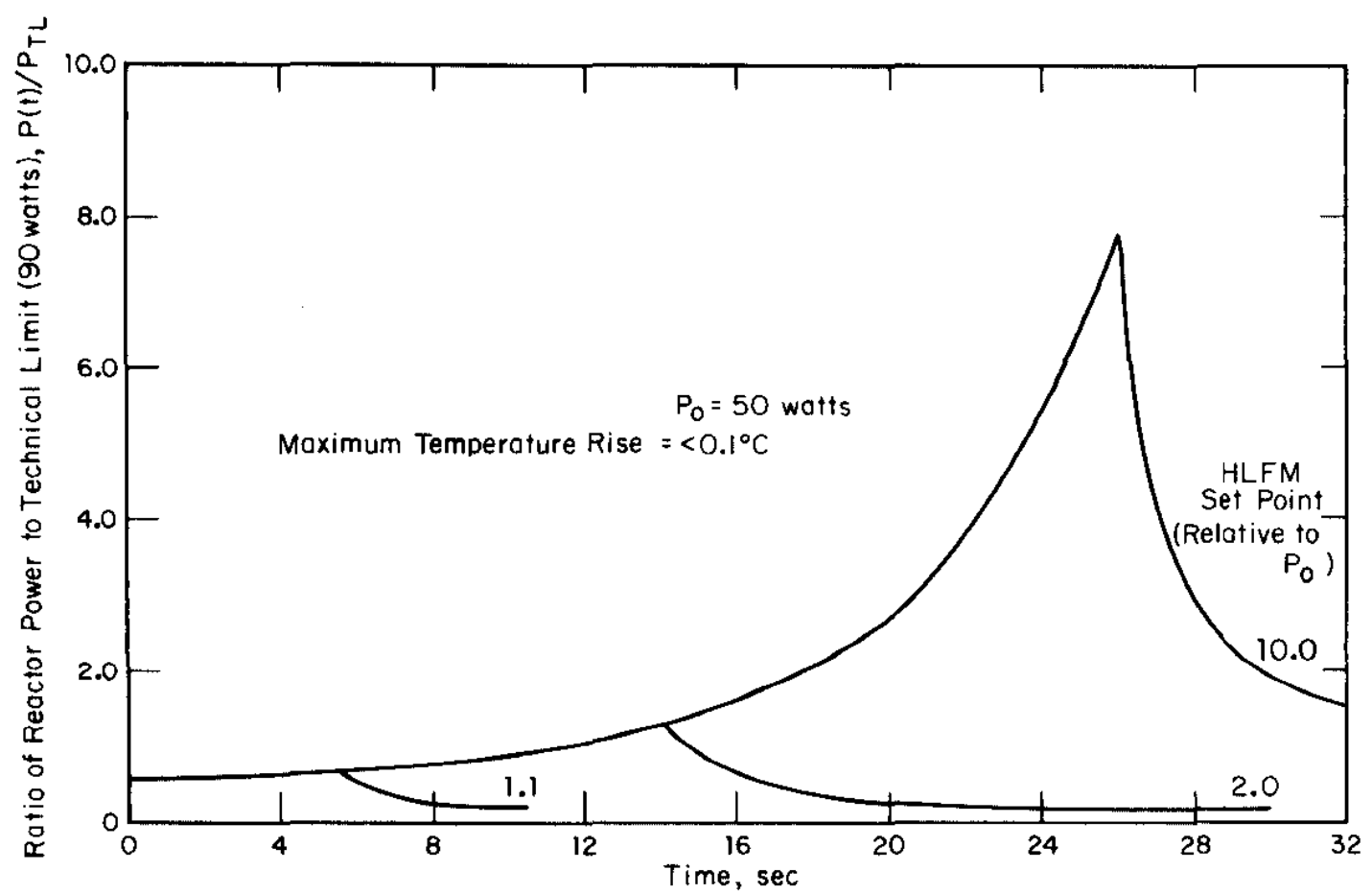

FIGURE 7. Shim Rod Driveout Incident with Different Scram Setpoints 
rod worth (Figure 4) and response times (Appendix, Table A-2) described earlier, and 2) the scram trip point were reached for any flux increase less than, or equal to, a factor of 10 . The effect of scram setpoints that permitted flux increases greater than a factor of 10 was not studied.

For this incident, in which an unauthorized test piece is inserted in the Test Pile, comprehensive general studies were done by varying the test piece reactivity worth, test piece drive speed, test piece length, and HLFM settings. These studies determined the conditions for which the scram system could make the pile subcritical. Specific cases can then be determined from the general studies.

The specific test pieces considered for this study were discussed earlier. The reactivity worths of these assemblies, when centered in the Test Pile and replacing a depleted target standard, are listed in Table 1. Only the full length U-A1 tube has the potential for adding reactivity in excess of the worth of the safety stem. The reactivity worth of the three other assemblies is so low that the scram system could easily prevent any significant temperature rise.

\section{TABLE 1}

Reactivity Worth of Test Pieces When Displacing a Depleted Target Standard

\begin{tabular}{|c|c|c|}
\hline & Total $\Delta k$ & \\
\hline Assembly & Long & Short \\
\hline $\mathrm{U}-\mathrm{A} 1$ tube, $200 \mathrm{~g}^{235} \mathrm{U} / \mathrm{ft}$ & $0.01590(12.5 \mathrm{ft})$ & $0.00520(2.1 \mathrm{ft})$ \\
\hline $\begin{array}{l}\text { Uranium metal, } 1.5 \%{ }^{235} \mathrm{U} \text {, } \\
\quad \sim 260 \mathrm{~g}^{235} \mathrm{U} / \mathrm{ft}\end{array}$ & $0.00450(15.4 \mathrm{ft})$ & $0.00260(2.1 \mathrm{ft})$ \\
\hline
\end{tabular}

The reactivity transient shapes for the $U-A 1$ test pieces of Table 1 are shown in Figure 8 . These two shapes are used for the general studies to be discussed below, but the total reactivity worth is varied.

\section{a. Long U-Al Test Piece}

When the pile scrams, either because of a too-high flux or too-short period, the test piece stops moving. Thus the scram systems limit the total reactivity that can be added to the pile. These limiting values are shown as curves in Figure 9 for long U-Al test pieces of different reactivity worths being inserted 
in the pile at $45 \mathrm{ft} / \mathrm{min} .(22.9 \mathrm{~cm} / \mathrm{sec})$. Similar limit curves for insertion speeds of $60 \mathrm{ft} / \mathrm{min} .(30.5 \mathrm{~cm} / \mathrm{sec})$ and $90 \mathrm{ft} / \mathrm{min}$. $(45.7 \mathrm{~cm} / \mathrm{sec})$ are shown in Figures 10 and 11 , respectively.

As explained above, for Figures 9, 10, and 11, the test piece is assumed to have the same shape reactivity transient as the $12.5 \mathrm{ft}, 200 \mathrm{~g}{ }^{235} \mathrm{U} / \mathrm{ft}, \mathrm{U}-\mathrm{Al}$ tube, and the total reactivity worth of the test piece is varied. Specific test piece cases can be obtained from the general limit curves.

If the Test Pile is subcritical after the pile scrams, then, for the cases considered in Figures 9, 10, and 11, the temperature rise will be less than $1^{\circ} \mathrm{C}$. In Figure 9, for example, if the test piece has a reactivity worth of 0.0200 (25\% more than the 0.01590 value for the long U-Al tube with $200 \mathrm{~g}{ }^{35} \mathrm{U} / \mathrm{ft}$ ) and the HLFM setpoint trips at a factor of 10 increase in flux, then the Test Pile would be barely subcritical after the scram. The computed power and peak temperature transients for this case are shown in Figure 12. The maximum temperature rise occurs in the test piece and is less than $0.4^{\circ} \mathrm{C}$.

\section{b. Short U-A1 Test Piece}

Limit curves for the reactivity worths that can be inserted in the Test Pile are shown in Figures 13, 14, and 15 for short U-A1 test pieces. For these figures, the test piece is assumed to have the same shape reactivity transient as the $2.1 \mathrm{ft}, 200 \mathrm{~g}$ ${ }^{2}{ }^{35} \mathrm{U} / \mathrm{ft}$, U-Al tube shown in Figure 8 . Only the total reactivity worth of the test piece is varied.

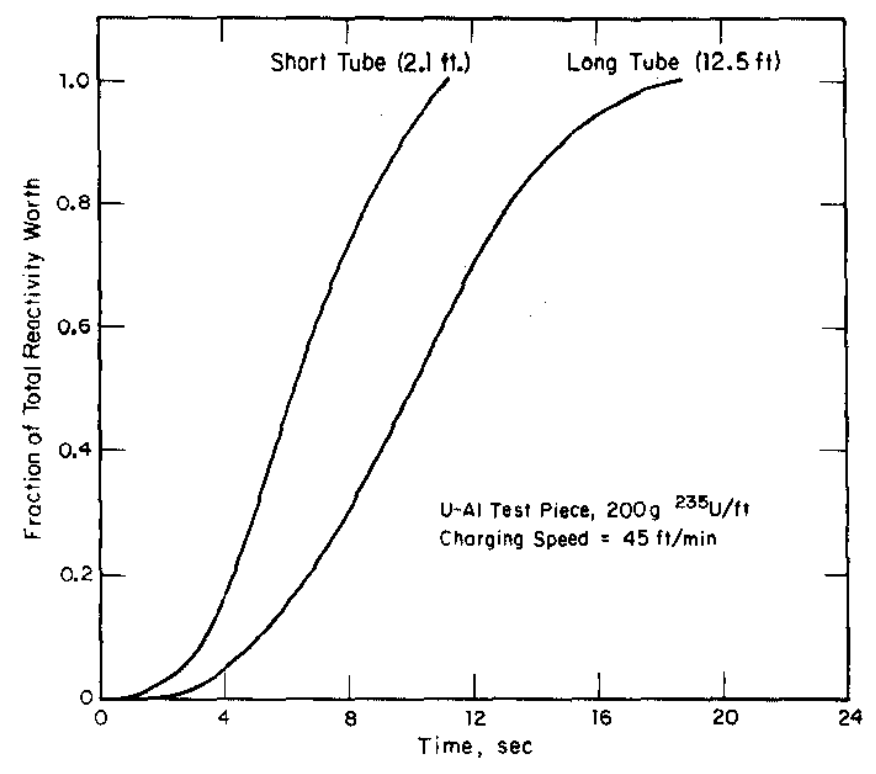

FIGURE 8. Reactivity Transients for Unauthorized Test Pieces 


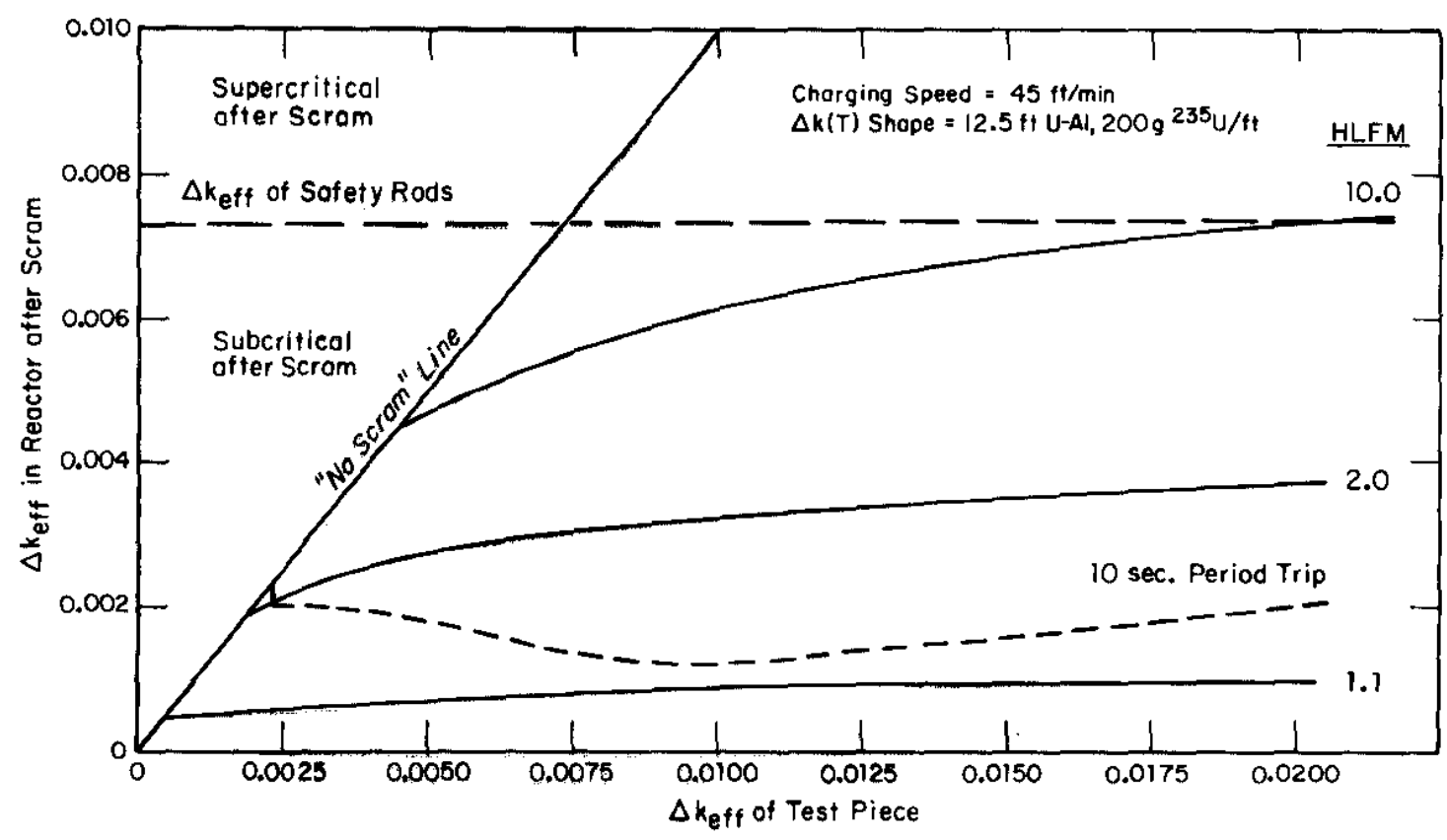

FIGURE 9. Reactivity Addition to Test Pile as Limited by Scram System Setpoints ( $12.5 \mathrm{ft} \mathrm{U-AT} \mathrm{rod} \mathrm{charged} \mathrm{at} 45 \mathrm{ft} / \mathrm{min}$ )

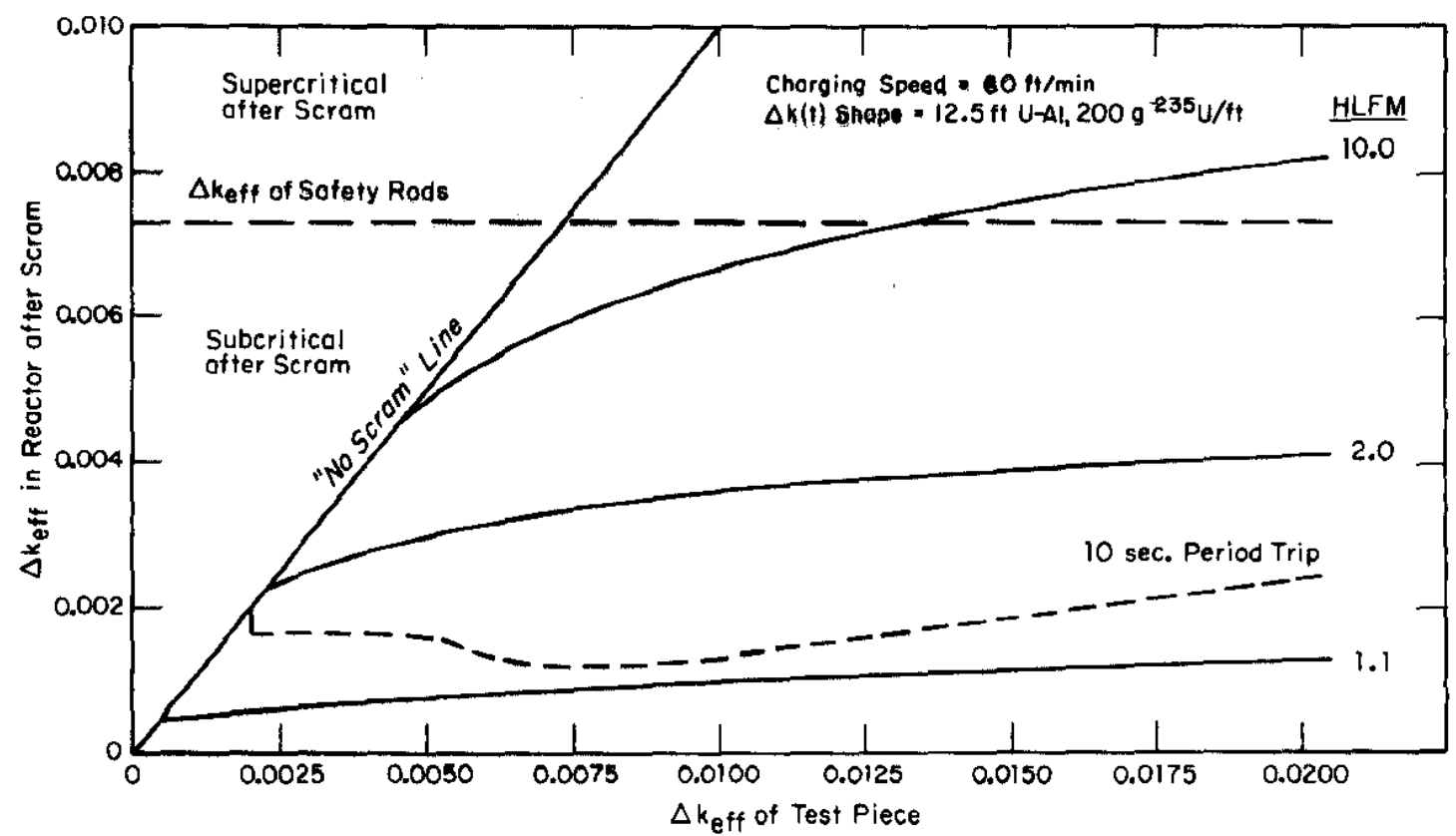

FIGURE 10. Reactivity Addition to Test Pile as Limited by Scram System Setpoints (12.5 ft U-AT rod charged at $60 \mathrm{ft} / \mathrm{min}$ ) 


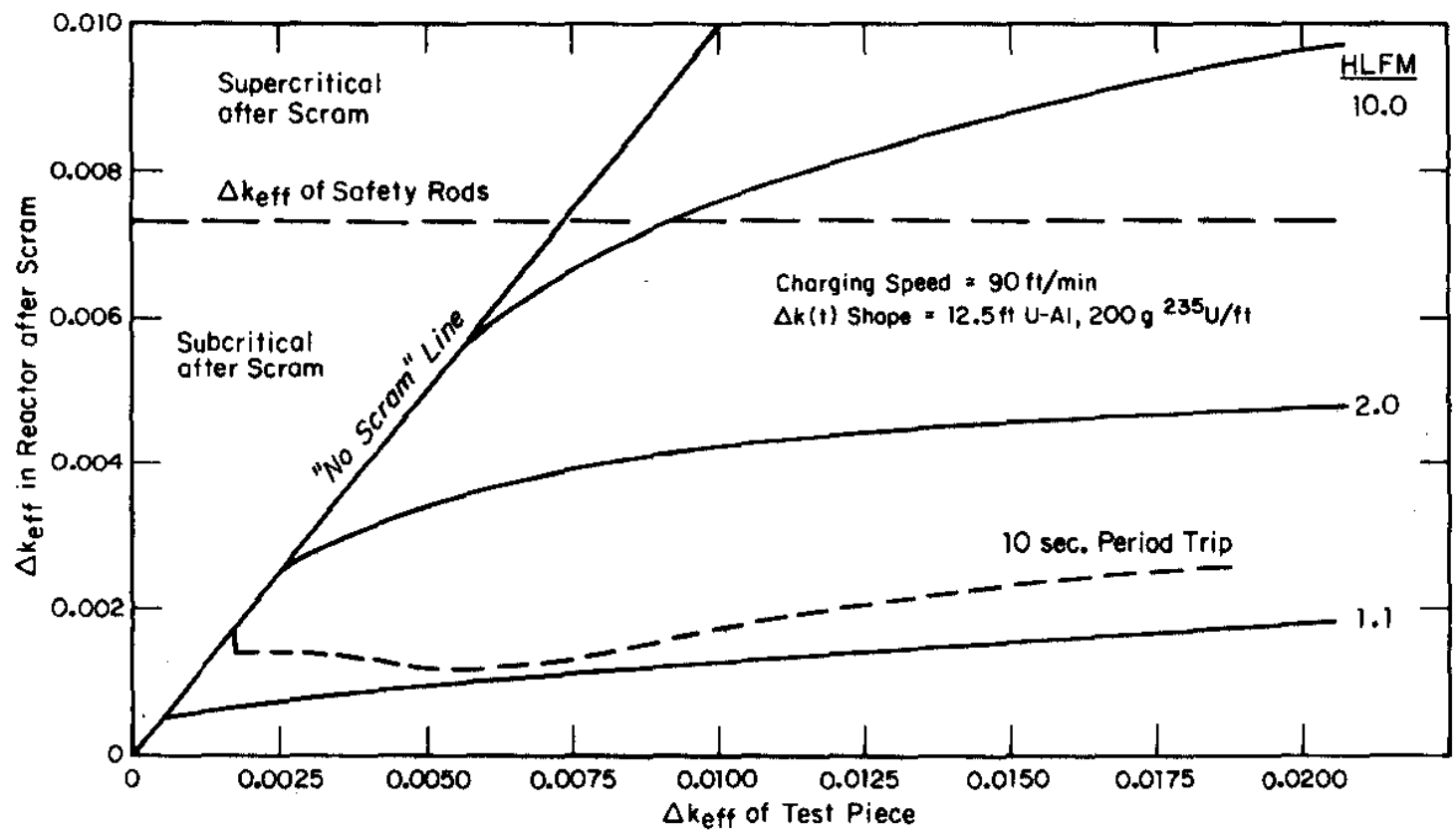

FIGURE 11. Reactivity Addition to Test Pile as Limited by Scram System Setpoints (12.5 $\mathrm{ft} \mathrm{U-A1} \mathrm{rod} \mathrm{charged} \mathrm{at} 90 \mathrm{ft} / \mathrm{min}$ )

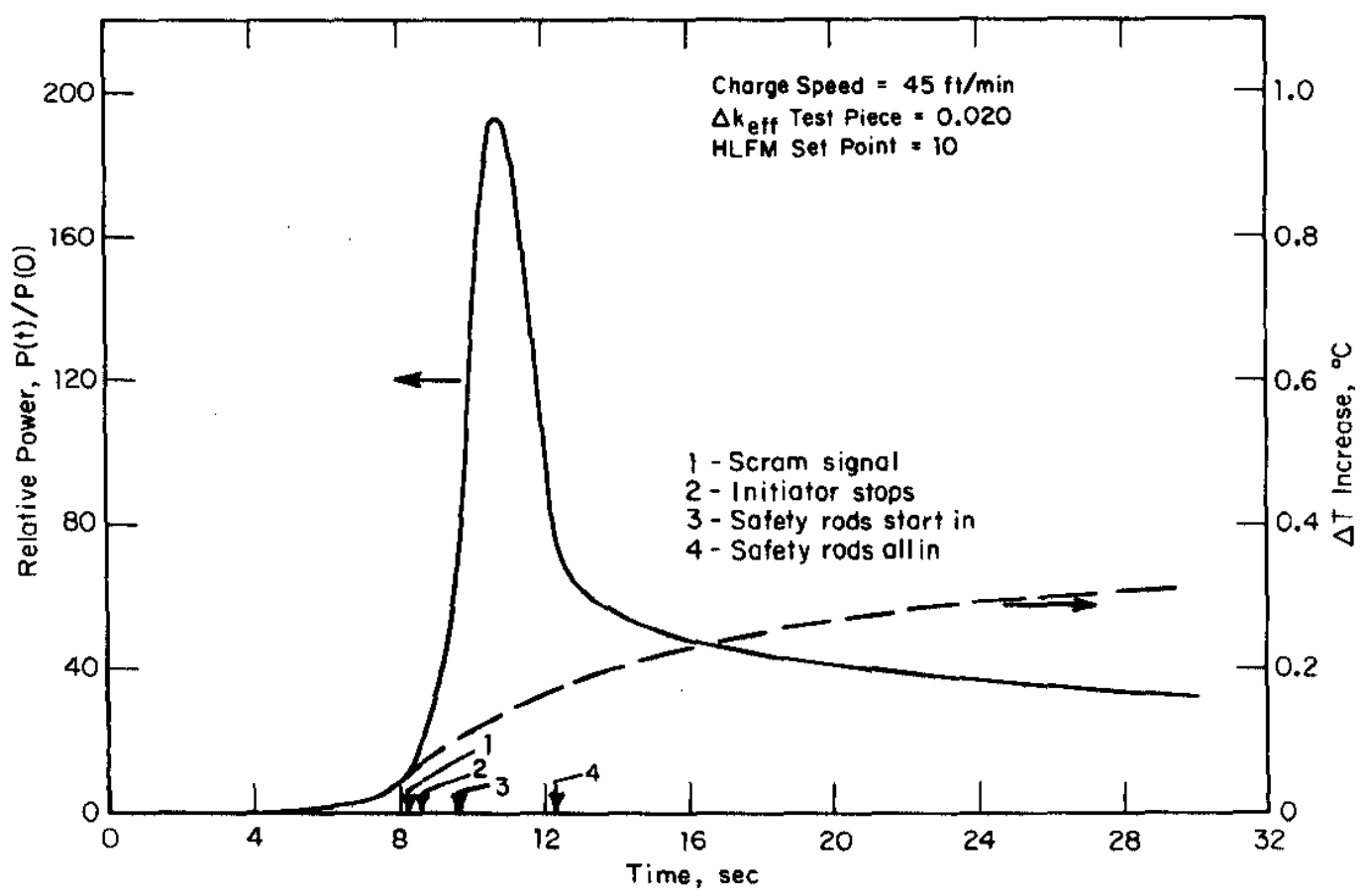

FIGURE 12. Power and Temperature Transients for U-Al Test Piece Incident 


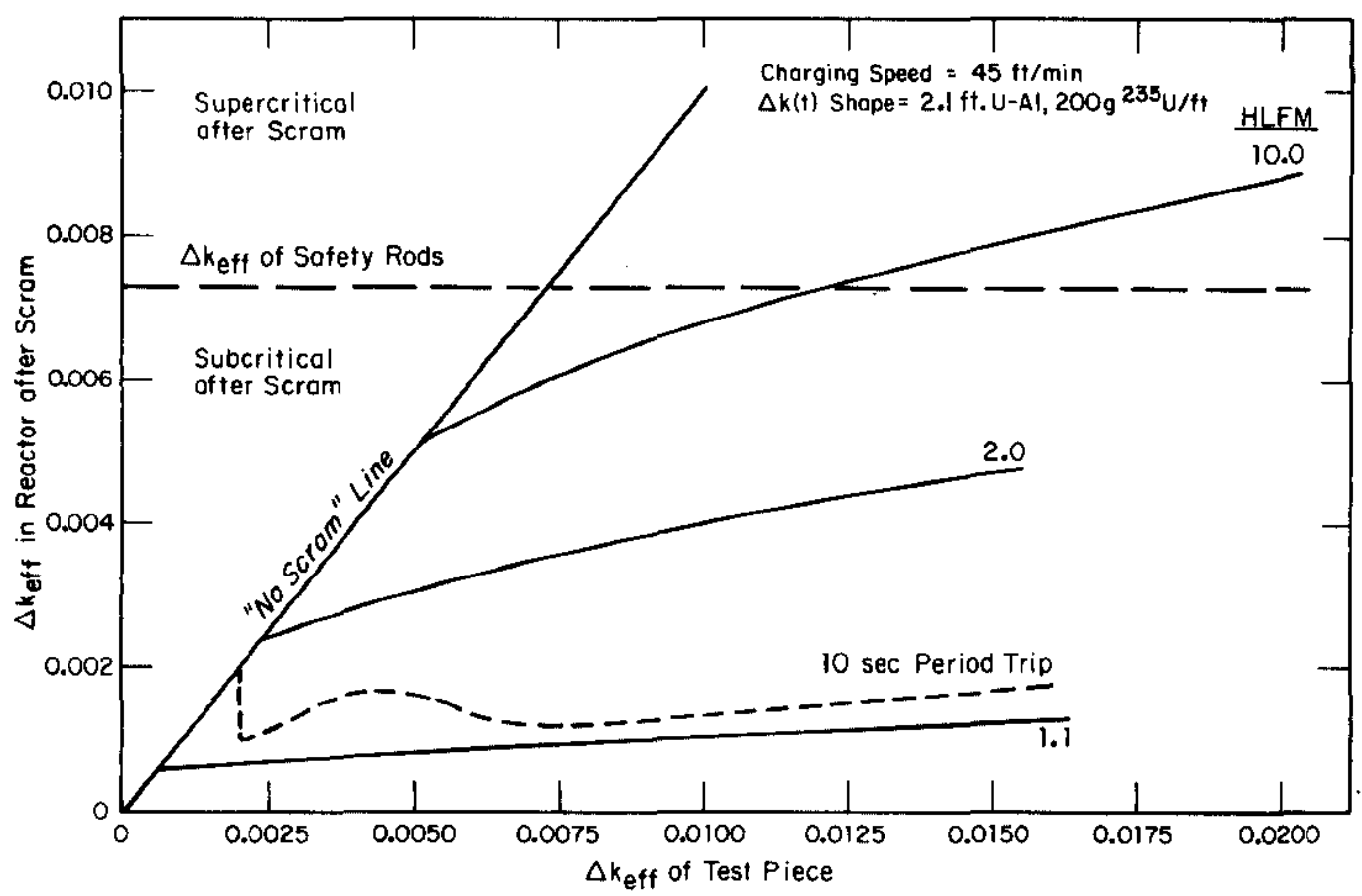

FIGURE 13. Reactivity Addition to Test Pile as Limited by Scram System Setpoints (2.1 ft U-AT rod charged at $45 \mathrm{ft} / \mathrm{min}$ )

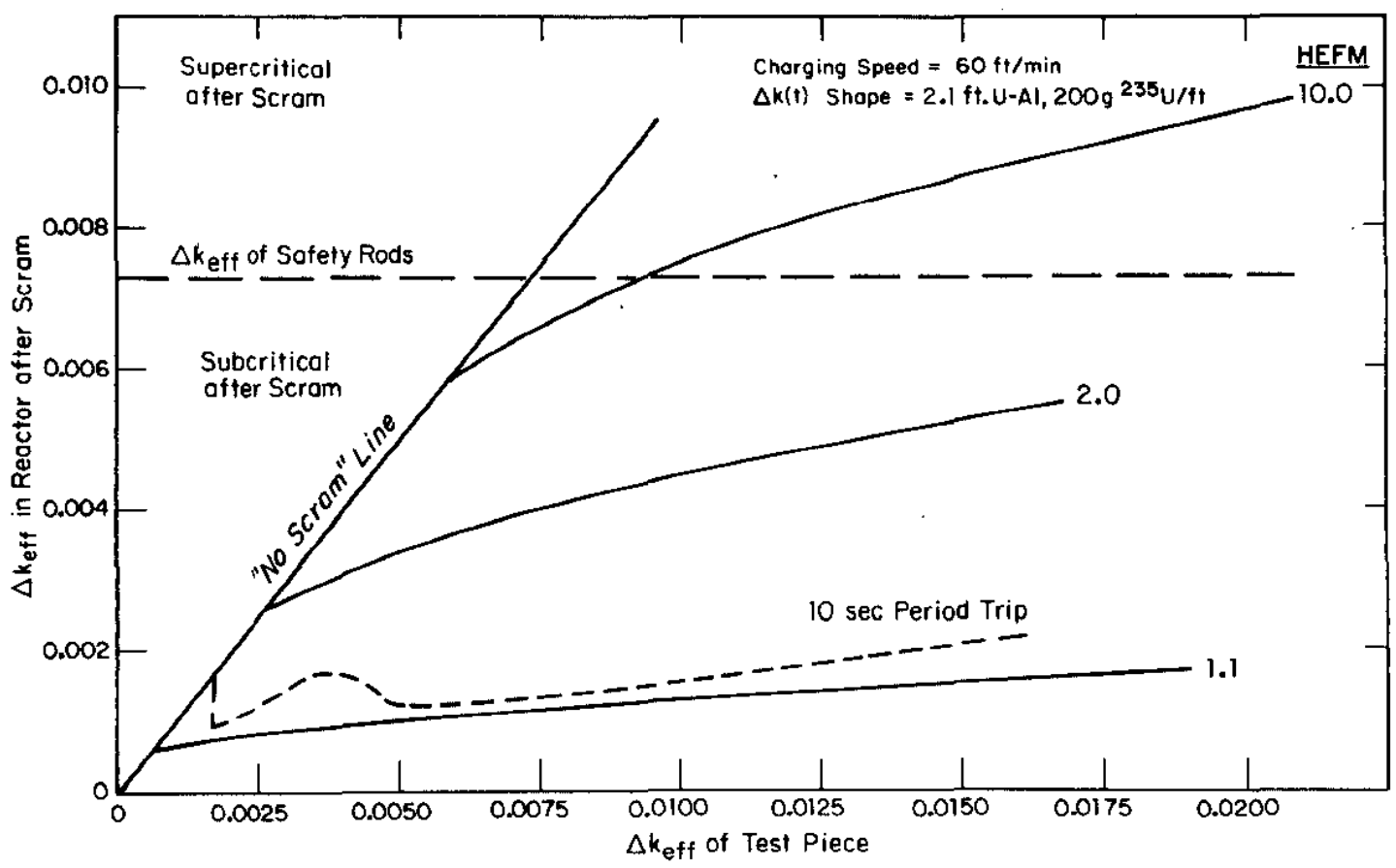

FIGURE 14. Reactivity Addition to Test Pile as Limited by Scram System Setpoints ( $2.1 \mathrm{ft} \mathrm{U-AT} \mathrm{rod} \mathrm{charged} \mathrm{at} 60 \mathrm{ft} / \mathrm{min}$ ) 


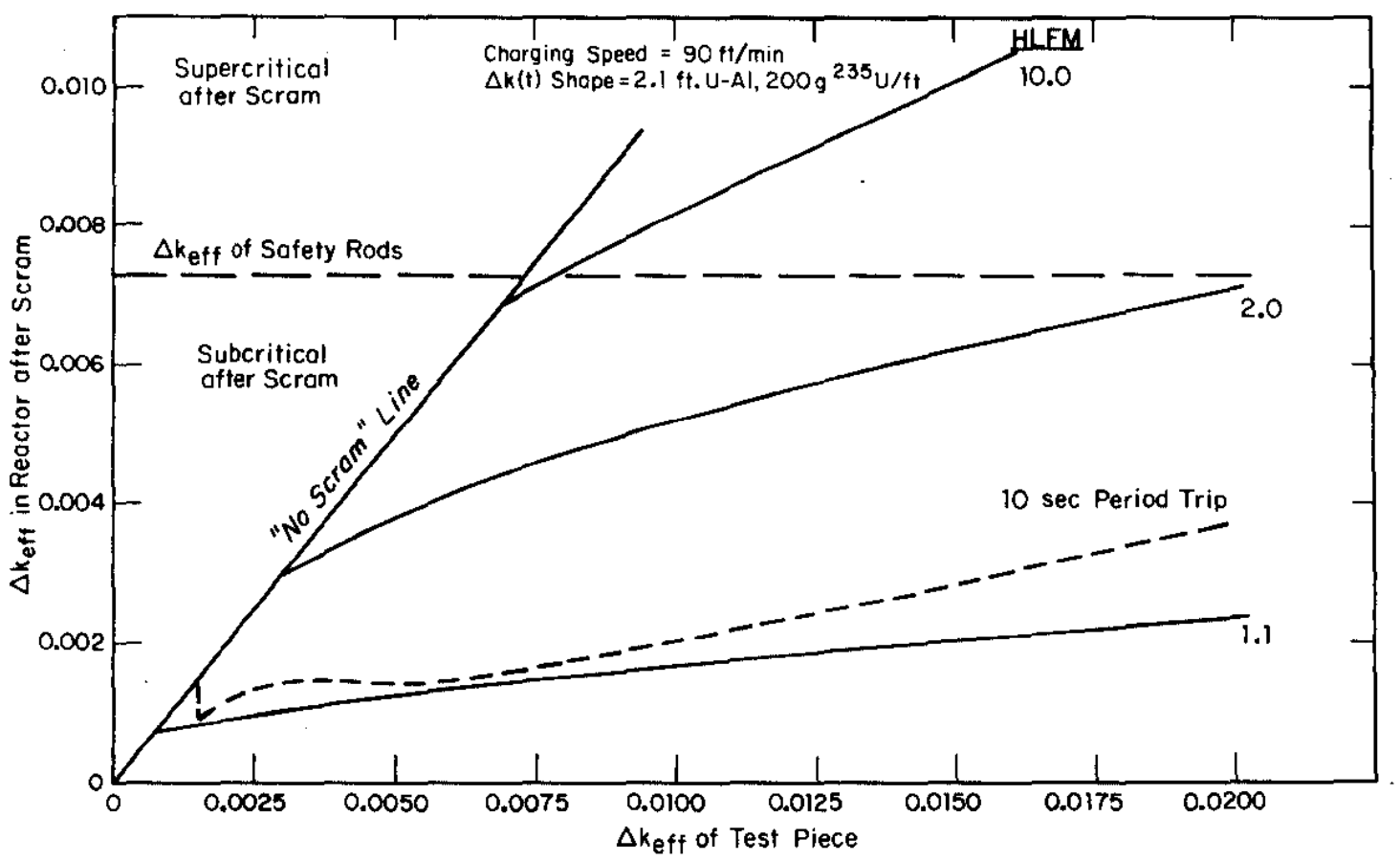

FIGURE 15. Reactivity Addition to Test Pile as Limited by Scram System Setpoints (2.T $\mathrm{ft} \mathrm{U-AT} \mathrm{rod} \mathrm{charged} \mathrm{at} 90 \mathrm{ft} / \mathrm{min}$ )

Table 2 lists the reactivity worths of the short test piece for various assumed ${ }^{235} \mathrm{U}$ loadings. Even when a short piece having $800 \mathrm{~g}{ }^{235} \mathrm{U} / \mathrm{ft}$ enters the Test Pile at $90 \mathrm{ft} / \mathrm{min}(45.7 \mathrm{~cm} / \mathrm{sec})$, and the flux increases by a factor of 10 before tripping a scram, the temperature rise does not exceed $1{ }^{\circ} \mathrm{C}$ anywhere in the pile. In fact, the safety rod reactivity worth assumed for this study (Figure 4) can prevent a $1^{\circ} \mathrm{C}$ temperature rise for any of the test pieces of Table 2 even if the test piece stringer does not stop when the pile is scrammed.

TABLE 2

Reactivity Worth of U-A1 2.1 ft Test Piece When Displacing a Depleted Target Standard

$\begin{array}{ll}{ }^{235} \mathrm{~J}, g / f t & \begin{array}{l}\text { Worth in the } \\ \text { Test Pile, } \Delta k_{e f f}\end{array} \\ 150 & 0.00488 \\ 200 & 0.00520 \\ 400 & 0.00616 \\ 600 & 0.00671 \\ 800 & 0.00711\end{array}$




$$
\text { c. Long and Short Uranium Metal Test Pieces }
$$

Uranium metal test pieces are not included in this general incident analysis because the temperature rise in these test pieces is always less than the temperature rise in a U-A1 assembly of equal reactivity worth. This smaller temperature rise in the uranium metal assemblies occurs because of the much higher heat capacity of the heavier uranium metal assemblies. However, the uranium metal test pieces of Table 1 are included in the accident analysis described in the next section.

Accident Analysis (Scram System Doesn't Work)

For this analysis, the scram system is assumed not to work. For the first and second types of accidents (rod driveout), the control rods are assumed to be driven completely out of the Test Pile. For the third type of accident (wrong test piece), the whole test piece is assumed to be inserted in the Test Pile. The negative reactivity effects caused by temperature increases in fuel and graphite and the self-shielding increase in melted metal are inherent shutdown mechanisms in the Test Pile that would end the transient. It is assumed that melting the test piece or fuel slugs would not remove reactive material from the core. Vaporization of the test piece would remove material from the core; however, computing this effect is beyond the scope of this study.

\section{Coarse Rod and Shim Rod Driveout Accidents}

The reactivity transient is slightly different for the shim rod driveout than for the coarse rod driveout. The end result is that all control rods are out of the pile. In either case, the final reactivity of the pile is the same, and the power ascends on the same stable period. The difference in the starting power of the two cases has little effect on the results. Figure 16 shows the power transient for both cases and 1ists the peak temperatures during the transient for the test piece and the hottest fuel slugs. Neither fuel nor test piece would melt, and no fission products would be released. 


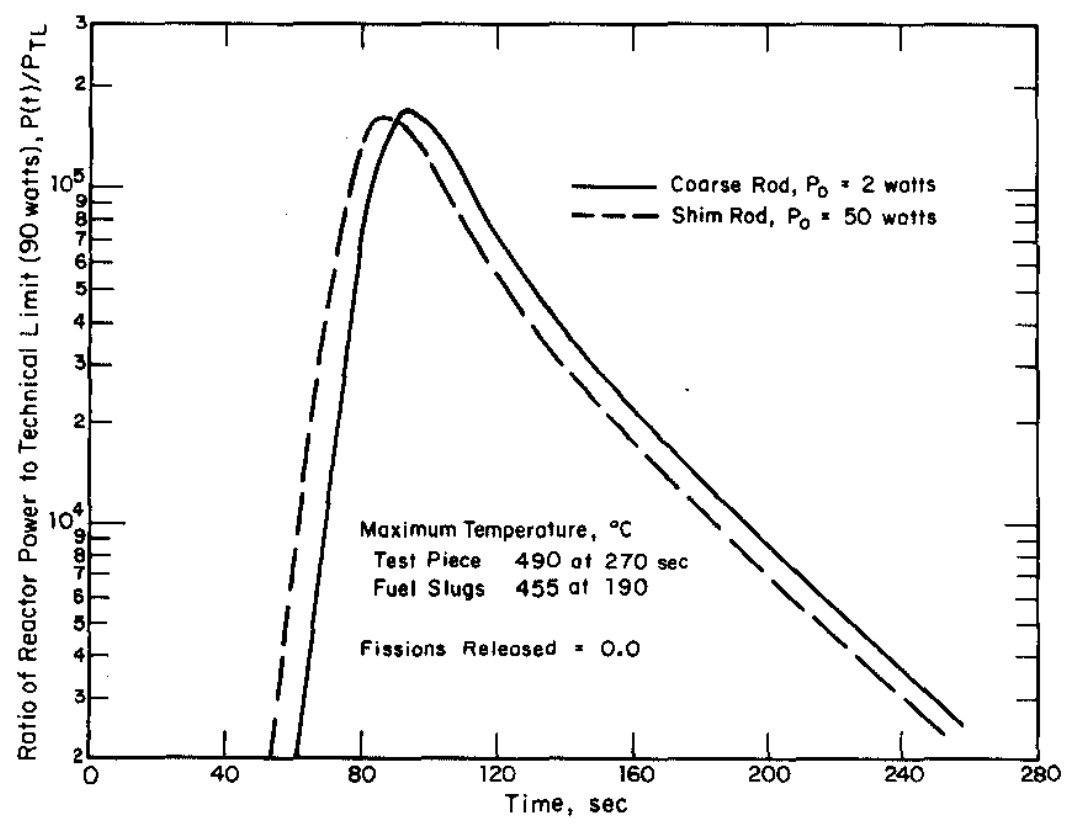

FIGURE 16. Reactor Transients for Control Rod Driveout Accidents

\section{Unauthorized Test Piece}

The U-Al and uranium metal assemblies considered in this accident (Table 1) differ not only in reactivity, but also in heat capacity and melting point.

Results of charging the uranium metal assembly to the Test Pile are calculated for the two different lengths considered (Figure 17). The peak temperatures within the Test Pile occur in the test pieces and are $2580^{\circ} \mathrm{C}$ for the full-1ength assembly and $\sim 345^{\circ} \mathrm{C}$ for the short assembly. Temperature increases in the fuel and graphite cause enough negative reactivity to end the power transient. Neither melting nor fission product release results. Figure 17 shows the fuel slugs cool faster than the test piece because the thermal conductivity of helium (around the fuel) is much greater than that for air (around the test piece). The peak metal temperature continues to decrease and the graphite temperatures (not shown) increase until an equilibrium temperature distribution is reached. At equilibrium, the negative reactivity from both fuel and graphite temperatures balance the positive reactivity of the test piece. 


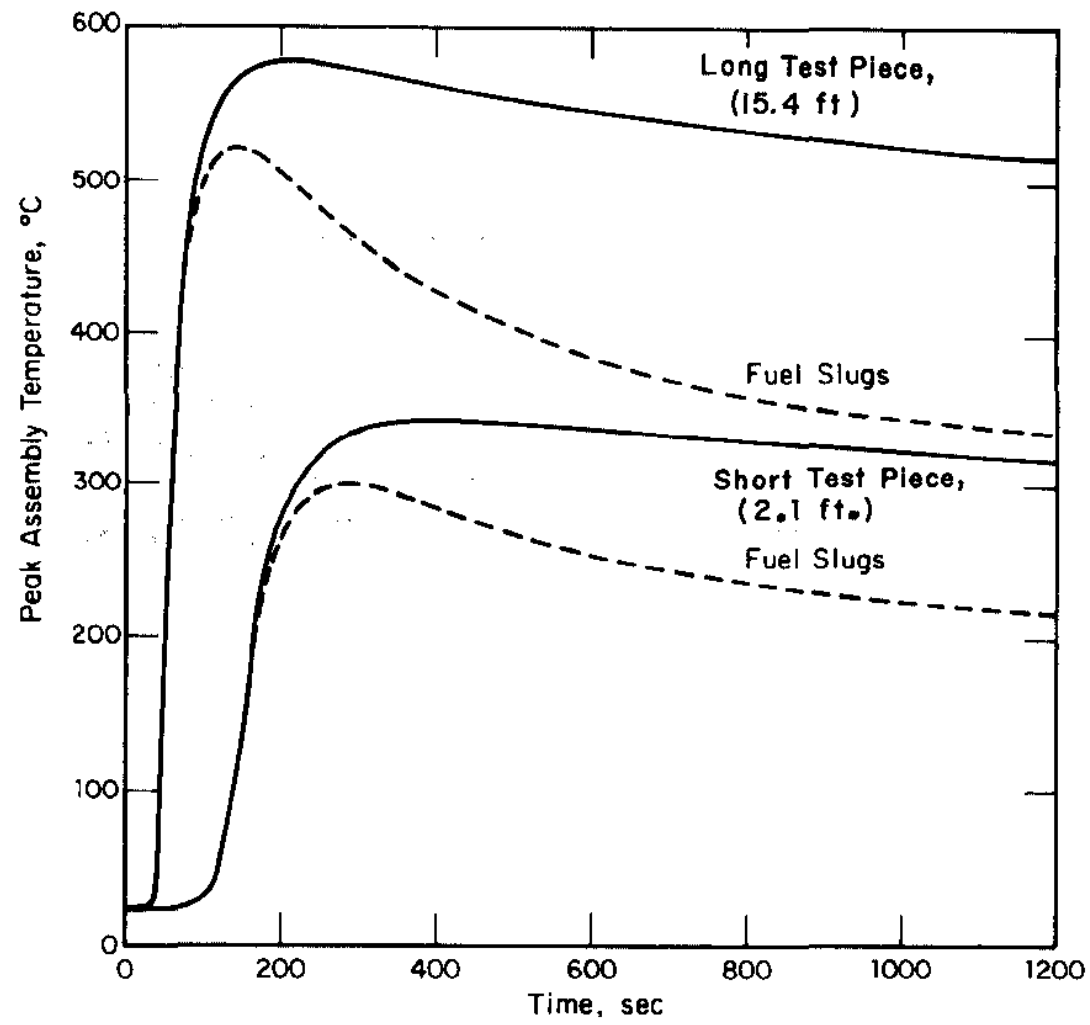

FIGURE 17. Temperature Transients for Insertion of Unauthorized Uranium Metal Assembly

The most severe accident calculated is for the full-length $\mathrm{U}-\mathrm{A} 1$ tube having $200 \mathrm{~g} / \mathrm{ft}{ }^{235} \mathrm{U}$ and being charged to the pile at $90 \mathrm{ft} / \mathrm{min}$ (twice the normal charging speed). For this case, the test piece partially vaporizes and some fuel slugs melt (Figure 18). The nuclear transient is over after ten minutes. By this time, the pile power drops to $400 \mathrm{~W}$, and most of the melted fue 1 (about 550 slugs) resolidifies. If the test piece did not ignite, it would partially resolidify. The cumulative fissions in molten metal at this time are about $1.02 \times 10^{19}$.

Even if the test piece were to ignite, propagation to the core is unlikely because graphite, which surrounds the test piece, will not ignite even at temperatures in excess of $4000^{\circ} \mathrm{K}$. 


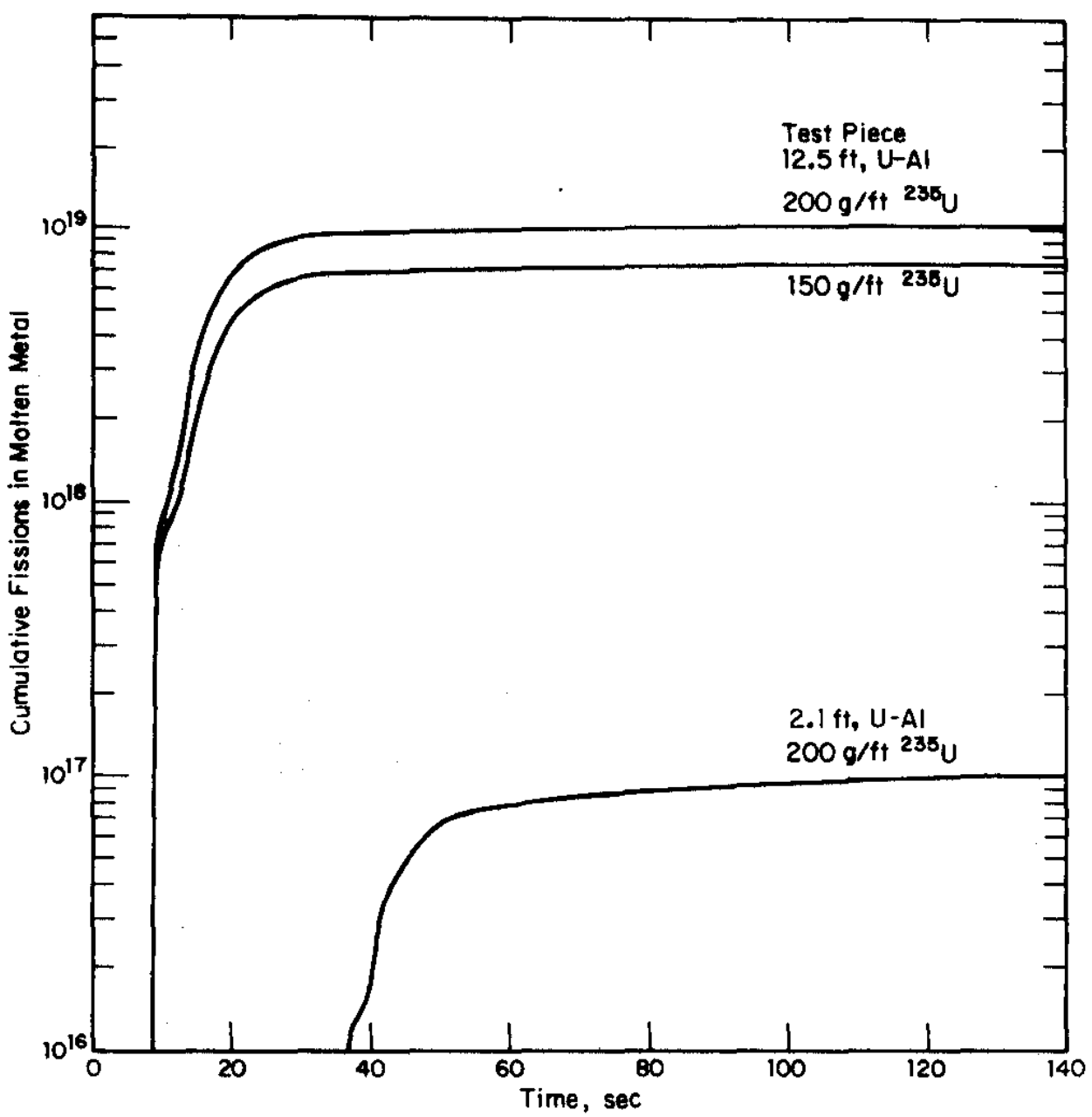

FIGURE 18. Total Number of Fissions in Molten Metal When Unauthorized U-A1 Assemblies are Charged at $90 \mathrm{ft} / \mathrm{min}$ to Test Pile 
The cumulative fissions in molten metal increase very rapidly at first as the test piece melts (Figure 18). The fuel slugs have a higher heat capacity, higher melting temperature, and lower specific power than the test piece, so the fuel would melt more slowly than the test piece. But as the fuel melted, the cumulative fissions in molten metal would continue to increase. Finally, the temperature increases in fuel and graphite would provide enough additional negative reactivity to end the transient. The power of the Test Pile is then so low that the cumulative fissions in molten metal remain almost constant.

The graphite stringer for holding the test pieces was modified to limit test piece lengths to about $2.1 \mathrm{ft}(64 \mathrm{~cm})$. Results for a $200 \mathrm{~g} / \mathrm{ft}$ U-Al tube of this length (Figure 18) would produce $1.02 \times 10^{17}$ fissions at the end of the nuclear transient, a factor of 100 less than for the $12.5 \mathrm{ft}(381 \mathrm{~cm})$ assembly. For this case, the test piece would completely melt. The peak temperature of the test piece would reach $\sim 1270^{\circ} \mathrm{C}$, well below the $1750^{\circ} \mathrm{C}$ at which U-A1 alloys might ignite. The peak temperature of the Test Pile fuel slugs would reach about $575^{\circ} \mathrm{C}$; thus no fuel slugs would melt.

\section{DOSE-TO-MAN THYROID EXPOSURE AT PLANT BOUNDARY}

The Code of Federal Regulations pertaining to atomic energy and designated $10-C F R-100^{4}$ specifies a guideline value of $300 \mathrm{rem}$ as a limiting accidental thyroid dose at the nearest boundary of the site exclusion area. Although the corresponding 10-CFR-100 guideline for whole body exposure is $25 \mathrm{rem}$, the thyroid dose guideline is more stringent for accidents of this type in which filtration of iodine is not assumed. The thyroid dose is assumed to be associated with a 95th percentile, i.e., the guideline dose will not be exceeded for $95 \%$ of the measured meteorological conditions at the site. Calculations of $24-\mathrm{hr}$ exposures (95th percentile) were based on:

- A criticality incident in which $10^{20}$ fissions occur.

- No fission product buildup before the incident.

- A release to the atmosphere of $50 \%$ of the iodine isotopes (as they are formed), $100 \%$ of the noble gases, and $1 \%$ of the other isotopes. The $1 \%$ value is increased to $50 \%$ for fuel that vaporizes during the transient.

- Releases to the atmosphere at ground level.

- SRP measured meteorological data. 
Dose estimates reflect the integrated effect of the total iodine released over a $24-\mathrm{hr}$ period following the postulated incident. During this period, the azimuthal wind direction varies and is determined by analyzing the meteorological data. Other dose rates for hypothetical incidents may be scaled directly on the basis of relative energy release, i.e., the relative number of fissions at shutdown.

As indicated in Table 3, no postulated accident in the Test Pile even approaches the 10-CFR-100 guide. The offsite exposure due to charging the long U-A1 test piece (200 $\left.\mathrm{g}^{235} \mathrm{U} / \mathrm{ft}\right)$ to the Test Pile is 20.0022 of the regulatory guidelines. Modifying the test piece stringer to limit test piece lengths to $2.1 \mathrm{ft}$ $(64 \mathrm{~cm})$ reduced the potential offsite exposure to $\approx 0.000022$ of the regulatory guidelines.

TABLE 3

Exposure at Plant Boundary Due to Fission Product Release from Molten Metal

24-hr-Thyroid Dose, rem (95th percentile)

10-CFR-100 guide1ine ${ }^{4} \quad 300$

$10^{20}$ fission excursion $\quad 6.4$

12.5-ft U-Al test piece, $200 \mathrm{~g}^{235} \mathrm{U} / \mathrm{ft}, 90 \mathrm{ft} / \mathrm{min} \quad 0.65$

12.5-ft U-Al test piece, $200 \mathrm{~g}^{235} \mathrm{U} / \mathrm{ft}, 45 \mathrm{ft} / \mathrm{min} \quad 0.28$

2.1-ft U-Al test piece, $200 \mathrm{~g}{ }^{35} \mathrm{U} / \mathrm{ft}, 90 \mathrm{ft} / \mathrm{min}$

0.0065

2.1-ft U-Al test piece, $200 \mathrm{~g}{ }^{35} \mathrm{U} / \mathrm{ft}, 45 \mathrm{ft} / \mathrm{min}$

0.0065 


\section{APPENDIX A. DESCRIPTION OF THE SRP TEST PILE}

\section{Location}

The SRP Test Pile is located on the Savannah River Plant site about 17 miles $(27 \mathrm{~km})$ south of Aiken, South Carolina. The building that houses the Test Pile is one mile $(1.6 \mathrm{~km})$ from the nearest plant boundary and three miles from the nearest town (Figure A-1). A complete site description of the area, including geology, hydrology, meteorology, and seismology data, may be found in Reference 6.

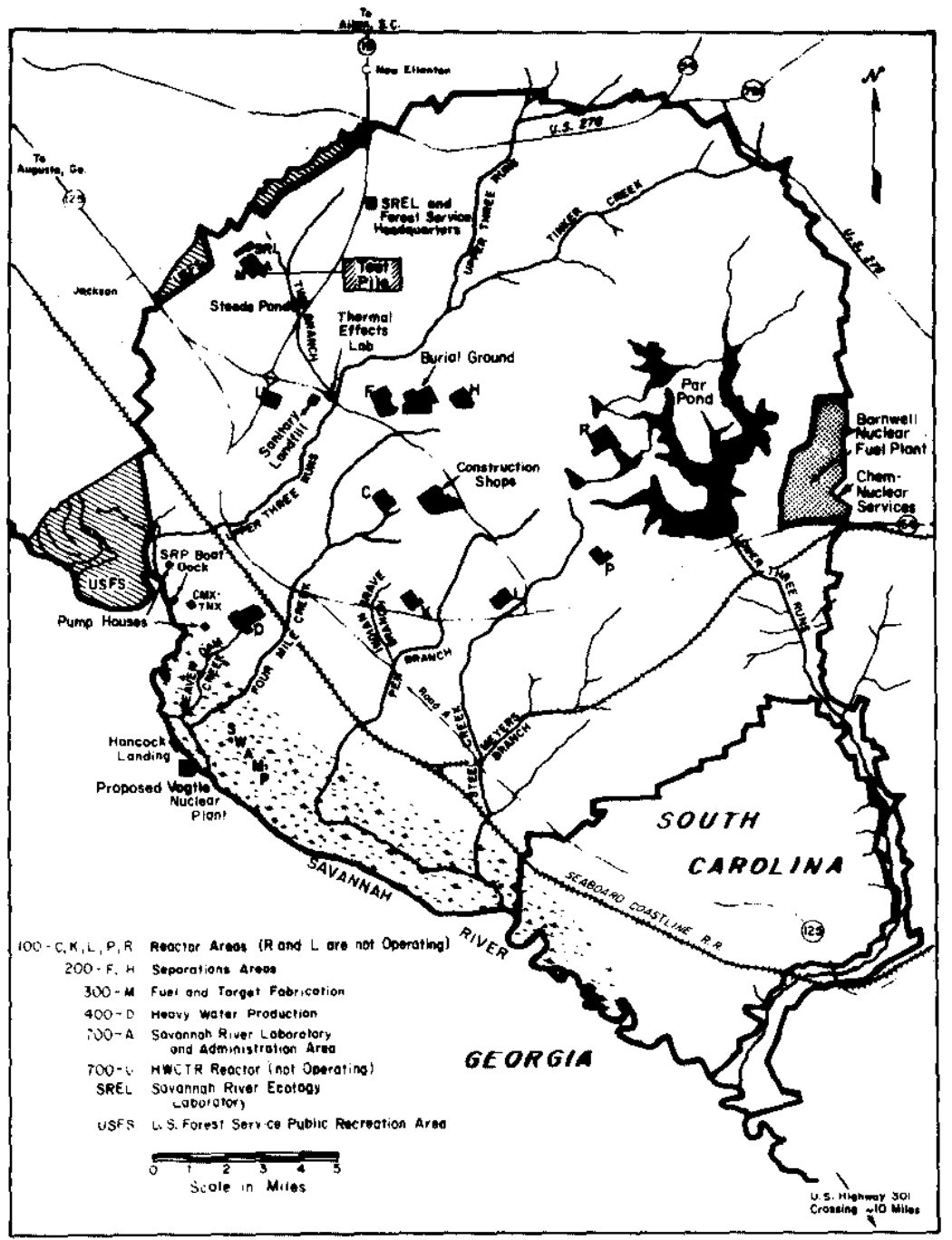

FIGURE A-7. Location of Test Pile on the Savannah River Plant 


\section{Description}

The SRP Test Pile is similar to the Hanford Test Pile. ${ }^{3}$ The SRP Test Pile is a graphite-moderated, natural-uranium-fueled, critical reactor designed to measure the reactivity worth of components for production or research reactors and to irradiate samples of miscellaneous materials. The reactivity difference between a test sample and a standard placed in the same position in the Test Pile is measured from the corresponding critical positions of a calibrated control rod.

The Test Pile and associated equipment are shown in Figure 1. The test pieces are placed on a motor-driven graphite stringer at the north face of the pile and driven into the pile. The pile is controlled during operation by three horizontal control rods that enter the west face. The automatic scram system operates three safety rods: one horizontal rod that enters the west face, and two vertical rods that drop in from the top of the pile.

\section{Core Design}

The core of the pile is shown in Figure 2 and is a graphite matrix about $15 \mathrm{ft}$ wide $\times 15 \mathrm{ft}$ long $\times 16 \mathrm{ft}$ high $(4.6 \mathrm{~m} \times 4.6 \mathrm{~m} \times$ $4.9 \mathrm{~m}$ ). Horizontal channels in the graphite extend through the pile and provide space for the fuel slugs. The $1.744-i n .(4.430-\mathrm{cm})-$ diameter channels are on an $8.375 \mathrm{in} .(21.27 \mathrm{~cm})$ square pitch. Each fully loaded channel contains 16 bare natural-uranium fuel slugs. The slugs are $1.44 \mathrm{in} .(3.66 \mathrm{~cm})$ in diameter and $8.25 \mathrm{in.}(21.0 \mathrm{~cm})$ long. Cylindrical graphite plugs of the same diameter as the fuel slugs and 1.063 in. $(2.70 \mathrm{~cm})$ long separate the slugs. A full column of 16 metal slugs and 15 graphite plugs is 148 in. $(376 \mathrm{~cm})$ long. The remaining $16 \mathrm{in} .(40.6 \mathrm{~cm})$ at each end of the channel are graphite.

Helium fills the gap between the fuel and graphite. The helium atmosphere eliminates fluctuations in reactivity caused by changes in atmospheric pressure. The reactivity effect due to changes in atmospheric pressure has been measured for a similar Hanford reactor as :

$$
\frac{1}{\mathrm{k}}\left(\frac{\Delta \mathrm{k}}{\Delta \mathrm{P}}\right)=-0.56 \times 10^{-5} / \mathrm{mm} \mathrm{Hg}
$$

To maintain the helium atmosphere, the core is enclosed with a 0.5 in. $(1.3 \mathrm{~cm}$ ) steel casing (Figure 3). Removable magnesium liners maintain a gas seal inside the test, instrument, and control rod holes. These liners are sealed at the ends into steel sleeves, which are welded to the steel casing. 
As shown in Figures 2 and 3 , the graphite provides at least a $16 \mathrm{in.}(41 \mathrm{~cm})$ reflector on all sides of the core. The reactor is shielded by $5 \mathrm{ft}(152 \mathrm{~cm})$ of concrete on the sides and top and is set on a 16 in. $(40.6 \mathrm{~cm})$ concrete slab which rests on the earth.

Although the core was designed to have several test holes, only Hole 3 (Figures 2 and 3 ) is now accessible for testing samples. Steel plates are bolted over all other test holes.

\section{Control System}

The Test Pile is controlled during operation by three horizonta1 control rods. These rods enter Holes 16 (fine rod), 25 (shim rod), and 26 (coarse rod) in the west face (Figures 2 and 3). The rods are driven at selected speeds of either $10 \mathrm{in.} / \mathrm{min}(0.4$ $\mathrm{cm} / \mathrm{sec})$ or $200 \mathrm{in} . / \mathrm{min}(8.5 \mathrm{~cm} / \mathrm{sec})$. The reactivity worth of the control rods is listed in Table A-1.

Under scram conditions (excepting electrical power failure), al1 control rods automatically drive into the pile at the selected speed. A manually turned handwheel on the drive shaft can also drive the shim rod into the pile.

All control rods are interlocked to prevent their withdrawa1 before safety rods are completely out of the pile. A spring-loaded switch can bypass these interlocks to check operation of the rod drive controls prior to startup. When released, the switch springs back to the unbypassed position.

\section{Safety System}

One horizontal and two vertical safety rods may be withdrawn simultaneously by cables on motor-driven winches. A magnetic clutch between the winch drive and drum is energized when the motor starts. When a scram signal or electrical power failure de-energizes the clutches, the two vertical safety rods fall freely into the pile; the horizontal safety rod is drawn into the pile by a counterweight. Safety rod worths are given in Table A-1.

\section{Emergency System}

Two hoppers containing neutron-absorbing shot provide additional safety protection. These hoppers are recessed in the top shield and can drop into two $3.0-$ in. $(7.6-\mathrm{cm})$-diameter vertical tubes that extend $214 \mathrm{ft}(426 \mathrm{~cm})$ into the pile. The combined reactivity worth of the shot from both hoppers is $1.16 \% \mathrm{k}$. 
TABLE A-1

Test Pile Control Rod and Safety Rod Systems

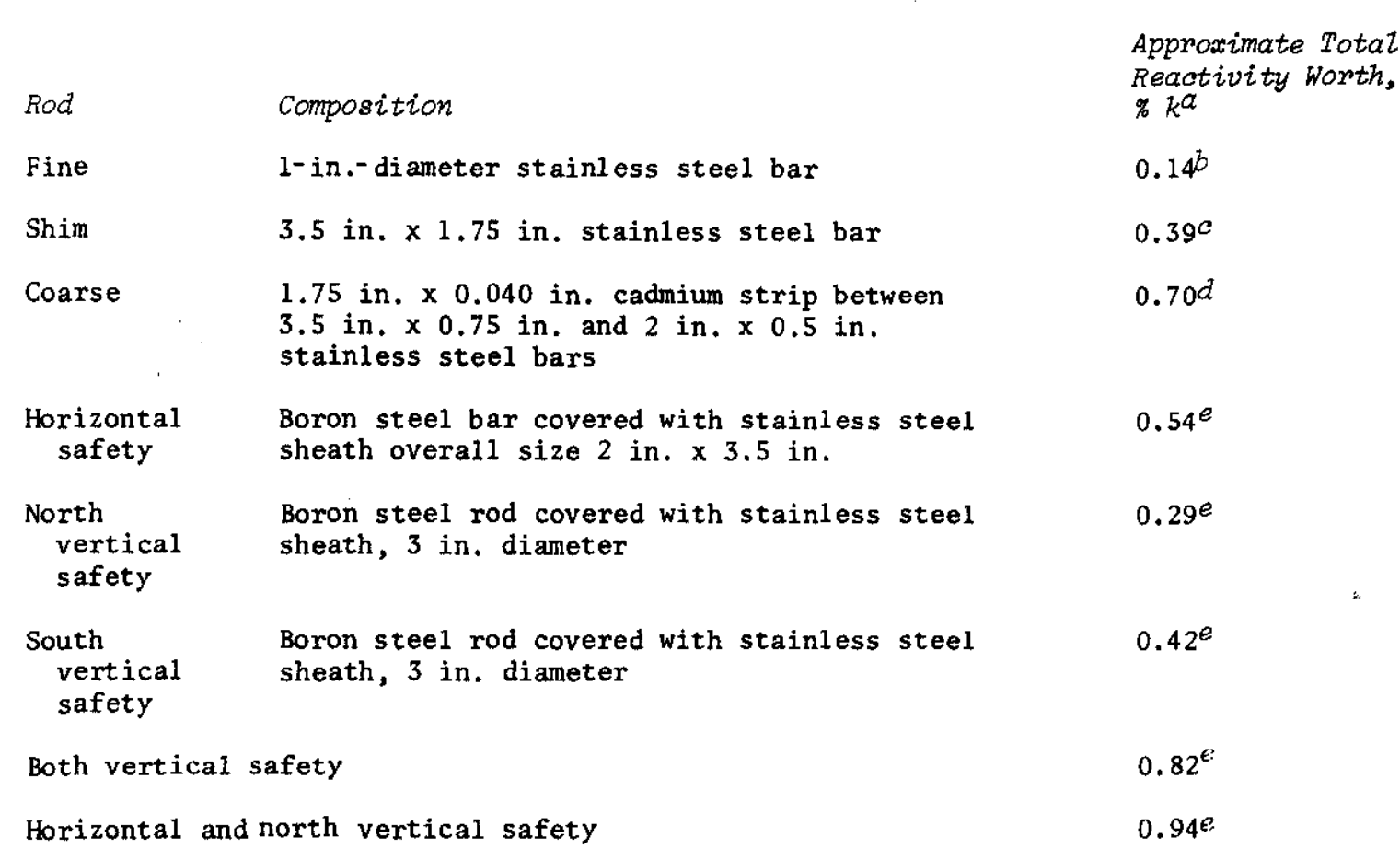

a. Actual worth depends on the location of all rods. The reactivity values shown have been measured by pulsed neutron techniques for the specific configurations listed in the table. All safety rods were out except for the specific rod being tested.

b. Coarse rod out, shim rod inserted 81 in. $(206 \mathrm{~cm})$, fine rod inserted.

c. Coarse rod inserted $44 \mathrm{in.}(112 \mathrm{~cm})$, shim rod inserted, fine rod inserted $118 \mathrm{in}$. $(300 \mathrm{~cm})$.

d. Coarse rod inserted, shim rod inserted 50 in. $(127 \mathrm{~cm})$, fine rod inserted 118 in. $(300 \mathrm{~cm})$.

e. Coarse rod out; shim rod and fine rod inserted as in $d$. 
A plug in the bottom of each hopper is held in place by a solenoid. An electrical power failure that interrupts the current to the solenoid for more than 3 seconds will cause the plugs to drop and the shot to fall. Pressing the EMERGENCY button on the control console will also release the shot (and release the safety rods and drive in all control rods). All shot enters the tubes within 30 seconds after the hoppers are opened.

A scram signal, either manual or automatic, does not deenergize the solenoids and will not release the shot.

\section{Instrumentation}

\section{Control Instrumentation}

A power-level galvanometer and a power-deviation galvanometer monitor the power level for normal operation. Current for the two galvanometers is supplied from five parallel-connected ion chambers. These ${ }^{10} \mathrm{~B}-1$ ined ion chambers are located in Holes 19, 20, 21, 22, and 23 on the west face of the pile (Figures 2 and 3 ).

\section{Safety Instrumentation}

There are four safety circuits that can automatically shut down (scram) the pile. Three of these detect pile power (low, intermediate, and high levels), and the fourth detects the pile period (the time in which the pile power increases by a factor of e). The circuits are independent except that they share the same master scram relay. The period circuit and intermediate power level circuit share a common ion chamber and amplifier.

The low-level, intermediate-level, and high-level circuits are normally set to scram at different power levels (typically, 50 to $75 \mathrm{~W}$, i.e., 1.5 to 2.5 times nominal operating levels). All use boron-coated ionization chambers. The chambers for the lowand intermediate-level circuits are in the east and west ends of Hole 17 (Figures 2 and 3 ). The chamber for the high-level circuit is in the west end of Hole 24 (Figures 2 and 3 ).

The period circuit can be adjusted to initiate a scram at any pile period exceeding 5 seconds. The circuit is normally set to scram at a period of 10 seconds. 
Each of the four safety circuits has a switch in series with the master scram relay coil. When any scram condition opens one of these switches, the scram relay is de-energized and initiates a scram. When a scram condition occurs, the horizontal and vertical safety rods enter the pile due to gravity, the fine and coarse rods are driven into the pile, and the test piece stringer stops (if it is moving).

The different safety circuits have different measured delay times that elapse between the detection of the scram condition and de-energizing the scram relay. The safety rod clutches have different demagnetization times for releasing the rods. Finally, the horizontal rod moves more slowly during insertion than the vertical rods. The measured values of these delay times and insertion times, as well as the conservative values used in this analysis, are listed in Table A-2. The scram.circuit response time and safety rod insertion time are illustrated in Figure $\mathrm{A}-2$.

TABLE A-2

Safety System Response Times for the SRP Test Pile

Event

Time, sec

1. T1, Time for scram relays to deenergize

- Flux Monitors

Linear No. 1

$0.25 \quad 0.4$

Linear No. 2

0.25

0.4

Log

0.03

0.4

- Period Detector

$0.49 \quad 1.0$

2. T2, Time for clutch to demagnetize and release rod

- NW vertical rod

$0.74 \quad 1.1$

- SE vertical rod

1.10

1.1

- Horizontal rod

0.76

1.0

3. T3, "Free-Fall" time for safety rod

- NW vertical rod

$0.85 \quad 0.9$

- SE vertical rod

0.83

0.9

- Horizontal

2.72

3.0 


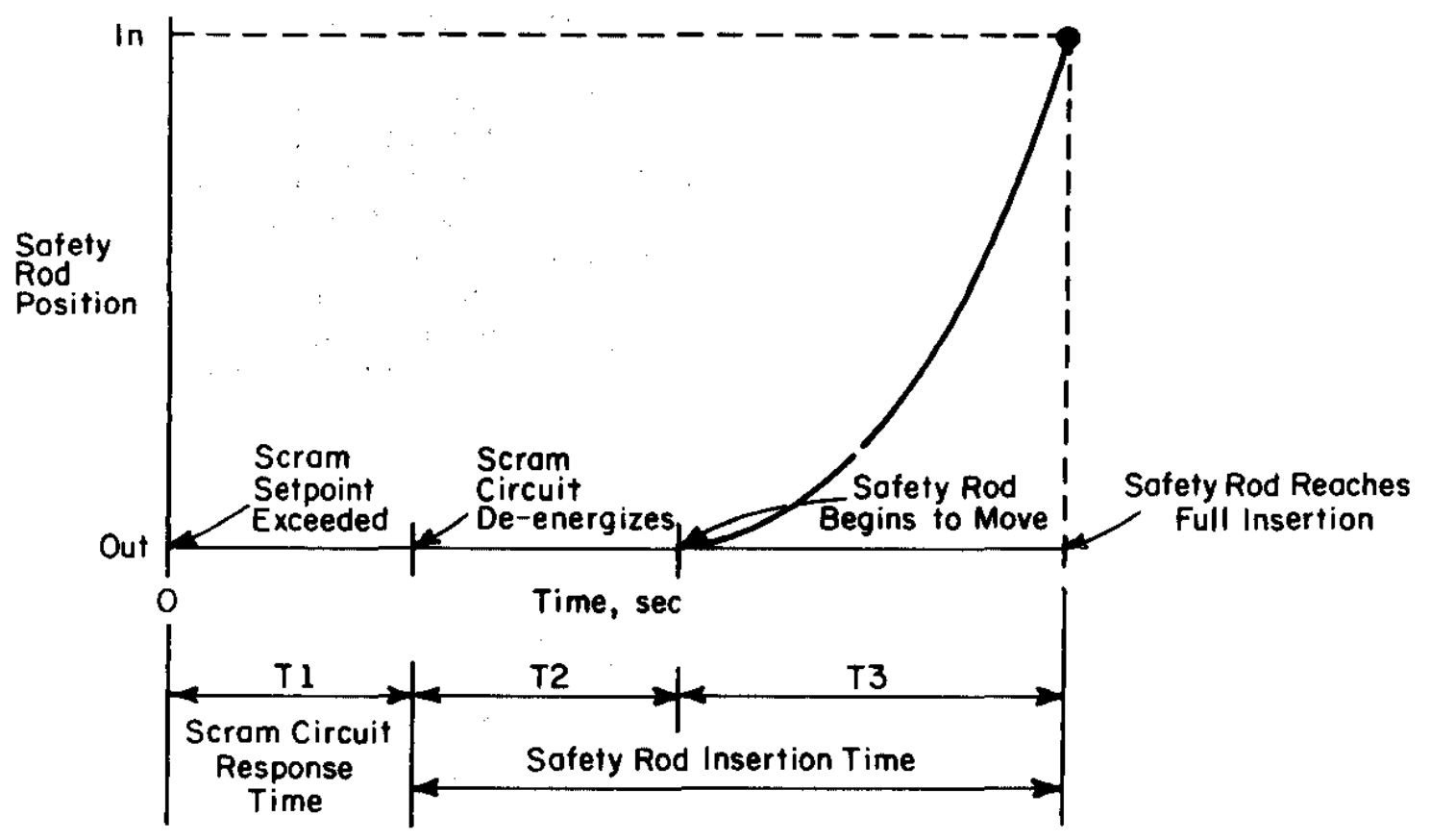

FIGURE A-2. Scram Circuit Response and Safety Rod Insertion Times 


\section{APPENDIX B. METHOD OF ANALYSIS}

The engineering characteristics of the Test Pile are very different from those of the SRP production reactors, so the standard accident analysis calculational system for the production reactors is not applicable. Thus, a new code, TESTPILE, was written to compute transients in the Test Pile.

The core is modeled in the TESTPILE code as a series of horizontal concentric annuli centered around the test hole (Figure B-1). The analyst chooses the size and number of these annuli to obtain the desired resolution of the temperature distribution across the reactor. Each annulus is characterized by its 1) fraction of reactor power produced, 2) number of Test Pile fuel channels, 3) axial distribution of power production, and 4) statistical weight functions for reactivity feedback caused by local temperature changes.

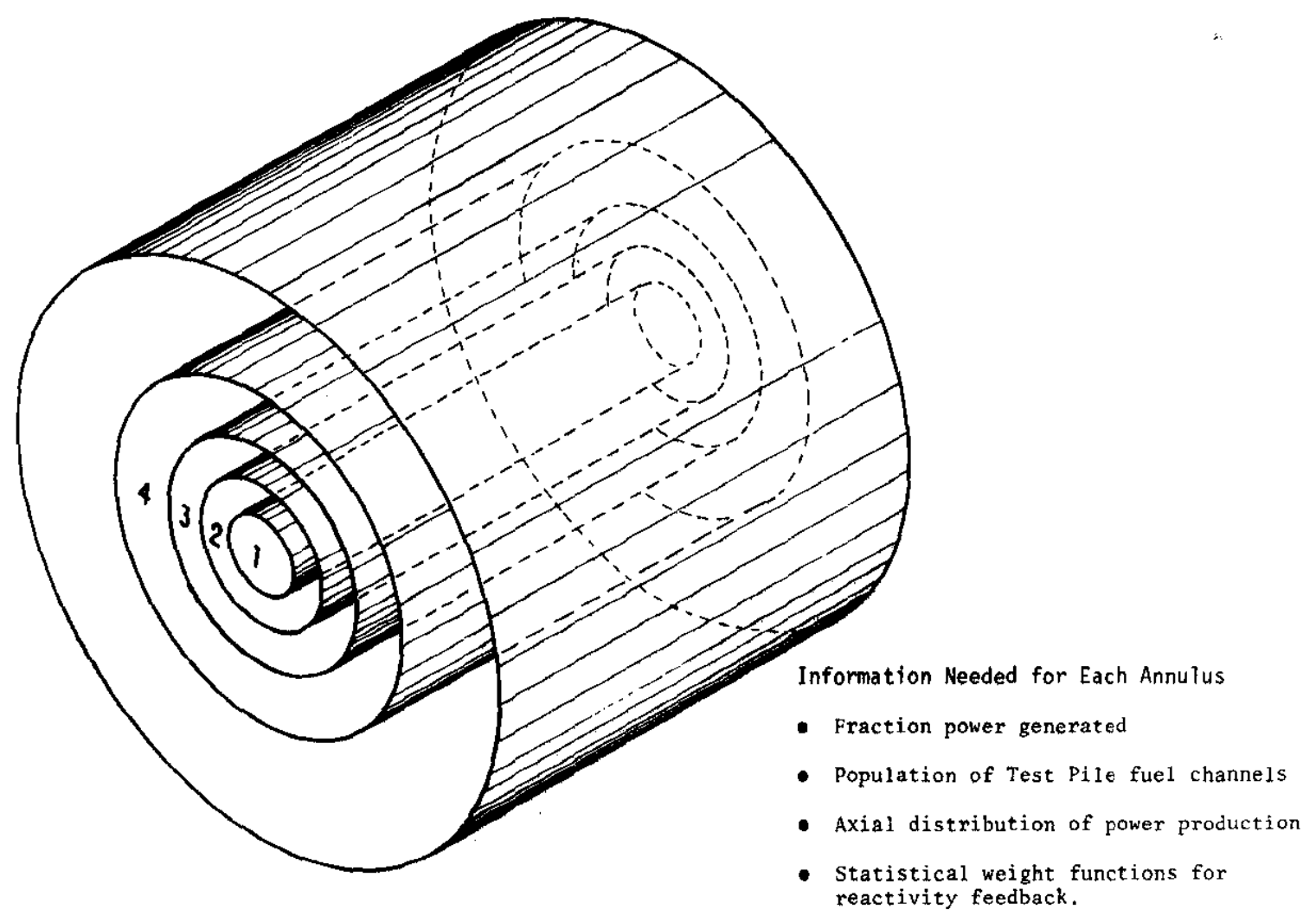

FIGURE B-1. Transient Analysis Model for Core of Test Pile 
These annuli data describe the spatial distribution of power in the pile. The transient response of the Test Pile is calculated by superposing this spatial distribution on a point-flux kinetics calculation. The spatial distribution changes with time as the control rods, safety rods, or test piece move, or as the temperature distribution changes in the pile. The time dependence of the power distribution can be approximated by precalculating static distributions under certain distinct physical conditions and then monitoring the kinetics calculation for the existence of those conditions.

However, the results of the transient calculations are much more sensitive to reactivity changes than to power distribution changes. Therefore, the reactivity worths of the control rods, safety rods, and test piece were calculated at several points of insertion to obtain accurate $\Delta K(t)$ transients for these initiators.

If the scram systems work, then the changes in power distribution caused by control rod, safety rod, or test piece movement will have little effect on the results. If the scram systems do not work, then the test piece is inserted fully into the pile or the control rods drive all the way out of the pile before the negative feedback effects can end the accident. Therefore, the changes in the flux shape during movement of the initiator will have little effect on the total release of fission products. Me1ting the test piece is the only cause of spatial redistribution of power significant for this study.

Thus, two distinct static flux shapes are used to produce the annuli data during the transient for calculating local power production and temperatures. These flux shapes are: 1) the static flux shape with the unmelted tubular test piece fully inserted (i.e., centered) in the Test Pile, and 2) the same condition but with the annular test piece melted to a rod shape. The control rod positions are the same for each of the two flux shapes, and correspond to the particular problem of interest.

The first flux shape is controlling until the test piece begins to melt, and the second flux shape applies when the test piece is completely melted. During the transition between the two conditions, a linear interpolation is made between the calculated annuli data for the two-flux shapes. The interpolation is based on the fraction of the test piece melted in each axial segment of the test piece.

The flux shapes and reactivity data were computed with the three-dimensional fewgroup diffusion theory GRIM code ${ }^{2}$ for various reactor configurations. A new code, GRMEDIT2, was written to edit the GRIM output (static flux shapes and fewgroup fission cross sections) and produce the distribution functions for power production and reactivity feedback. 
The GRIM output provides flux and cross section data for each axial segment along each fuel channel of the pile. GRMEDIT2 computes the fission power production at each of these locations and then scans along each fuel channel to find the peak power production. The peak values for each fuel channel are then normalized to a scale of 0 to 999 and displayed as a face map of the pile (Figure B-2). The analyst then studies this display and decides how to group the assemblies by drawing the annuli boundaries. This grouping information is input to GRMEDIT2, and that code is run a second time. The output of this second run is the annuli data that can be read directly by the TESTPILE code.

The TESTPILE code computes the time-dependent power and temperature response of the pile assuming the annular model discussed earlier (Figure B-1). Within each TESTPILE annulus, all fuel channels are assumed to be identical. The heat flow between the fuel (or test piece) and graphite is first computed assuming heat transfer by radiation and conduction. Then the heat flow between adjacent annuli is computed assuming heat conduction between homogeneous graphite regions, with each region at a uniform temperature.

An equilibrium temperature distribution is computed at the beginning of the transient, and the departure from that distribution determines the computed reactivity feedback. The transient is calculated and then computed as a direct numerical integration of the heat transfer and point kinetics differential equations. The temperature dependence of coefficients, such as thermal conductivity, specific heat, density, etc., are built into the code and are computed at each time step.

TESTPILE output includes a) the temperature transient of the hottest axial segment in the metal and graphite in each annulus, and b) the cumulative fission energy (produced in molten metal) that is available for potential release outside the pile. 
MAXIMUM FISSION POWER IN EACH ASSEMBLY

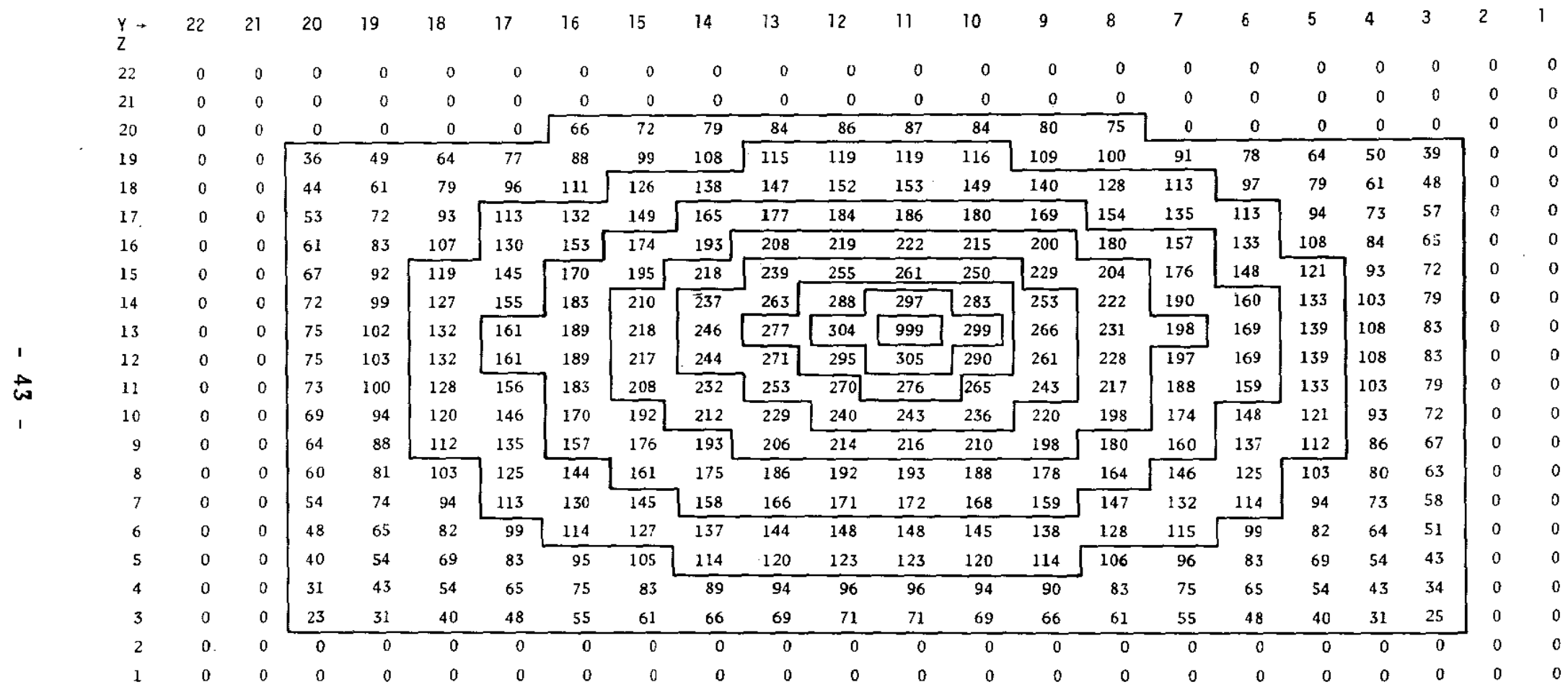

FIGURE B-2. Face Map of Test Pile Showing Relative Values for Peak Axial Power Production 


\section{REFERENCES}

1. The JOSHUA System, Vo1. 4, "Lattice Physics." DPSTM-500, Savannah River Laboratory, E. I. du Pont de Nemours and Co., Aiken, South Carolina (1970).

2. The JOSHUA System, Vo1. 6, "Static Reactor Physics." DPSTM500 , Savannah River Laboratory, E. I. du Pont de Nemours and Co., Aiken, South Carolina (1972).

3. R. Nilson. Hazards Sumary Report, Hanford Test Reactor (305 PiZe). USAEC Report HW-80600, General Electric Co., Hanford Atomic Products Operation, Richland, Washington (1964).

4. Code of Federal Regulations. "Reactor Site Criteria." Title 10, Part 100,10-CFR-100. Oak Ridge Technical Information Center, Oak Ridge, Tennessee (1975).

5. ERDA Manua1, Chapter 0524. Oak Ridge Technical Information Center, Oak Ridge, Tennessee (1975).

6. W. L. Marter and T. M. Langley. The Savannah River Plant Site. USAEC Report DP-1323, Savannah River Laboratory, E. I. du Pont de Nemours and Co., Aiken, South Carolina (1975). 